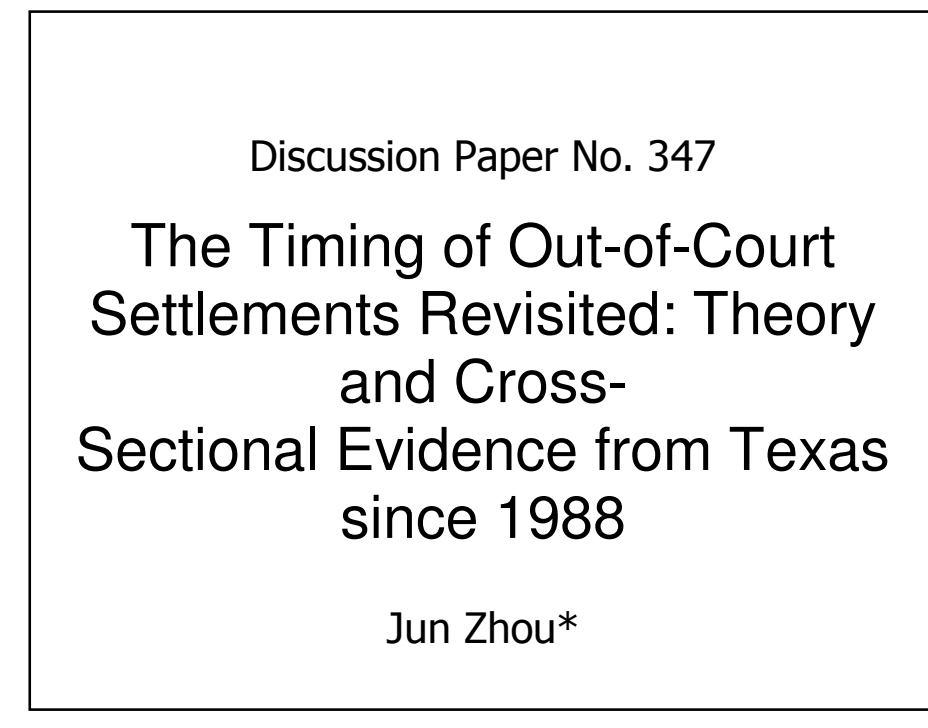

*University of Bonn

December 2010

Financial support from the Deutsche Forschungsgemeinschaft through SFB/TR 15 is gratefully acknowledged. 


\title{
The Timing of Out-of-Court Settlements Revisited: Theory and Cross- Sectional Evidence from Texas since $1988^{1}$
}

\author{
Jun Zhou, Wirtschaftspolitische Abteilung, Bonn University
}

Legal institutions play an important role in affecting delay in settlement. But little research has investigated the institutional causes of delay. The empirical literature is ambiguous regarding the impact of trial-court delay on settlement delay. I analyze the timing of bargaining and the causes of delay using a cross-section of insurance claims in Texas over a 20-year span. I discuss a dynamic model of pretrial negotiation to illustrate how changes in the legal systems might affect the duration of settlement. Comparative statics results are then corroborated with empirical estimates of a hazard function adjusted to account for the heterogeneity of claims and the time dependence suggested by theory. Statistical tests are consistent with the theoretic prediction that delay in trial courts expedites out-of-court settlement. I also find that alternative dispute resolution, a legal process designed to save transaction costs, reduces the rapidity of settlement. Prejudgement interest, a law introduced to reduce delay, actually causes a greater delay in settlement. The results have implications for efficiency of the judicial system and reform efforts aiming to reduce delay. Journal of Economic Literature Classification Numbers: C78, K41.

Keywords: settlement delay, trial-court delay, prejudgment interest, alternative dispute resolution

\section{INTRODUCTION}

Delays in the resolution of legal disputes are commonplace. Bodily injury claims in Texas take, on average, 26 months to settle. ${ }^{2}$ In the UK, cases sampled for Lord Chancellor's Department (1986) and by Swanson (1988) indicate that filed cases take between 18 and 40 months to reach trial. In Italy, 12 to 13 years are expected for the final determination of a civil dispute. ${ }^{3}$ The purpose of this paper is to study what factors determine the duration of settlement. My main interest is in the institutional

\footnotetext{
${ }^{1}$ The paper is an extensively revised version of chapter 2 of the author's Ph.D. thesis. An earlier version of this paper has been presented at American Law and Economics Association 18th Annual Meeting and the 2008 European Meeting of the Econometric Society. I benefited from conversations and suggestions about this research from Jan Boone, Daniel Kraehmer, Kathryn Spier, Jaap Abbring, Paul Fenn, Bertrand Melenberg, Jan van Ours, Tobias Klein, Ronen Avraham, an anonymous referee, Charles Silver, Bernard Black, Kowsar Yousefi and the Ph.D. defense committee members. I am grateful to Vicky Knox at the Texas Department of Insurance, Joni Hersch, Jeffrey O'Connell and David Hyman for their advice on handling the data. Special thanks go to Eric van Damme and Urs Schweizer for their patient and crucially insightful supervision on this project. Support from the Netherlands Organisation for Scientific Research (No. 400-03-296) and the German Research Foundation through SFB TR 15 is gratefully acknowledged. Any mistakes are my own.

Send correspondence to: Dr. Jun Zhou, Wirtschaftspolitische Abteilung, Bonn University, Adenauerallee 24-42, 53113 Bonn, Germany; Email: okonom.bonn@gmail.com

${ }^{2}$ See Table 2, Panel A. Fenn and Rickman (1999) report similar delay figures for medical negligence and employee claim cases filed in UK, as do Worthington (1991) for motor vehicle accident cases in New South Wales and Kakalik et al. (1990) for civil cases filed in Los Angelas.

${ }^{3}$ See Varano (1997).
} 
causes of delay in pretrial negotiations. This is worthwhile because the the analysis can shed light on the allocation of resources in the civil justice system and social welfare. For example, knowing which institutional factors reduce settlement delay allows policy makers to design policies that encourage early settlements and hence places less stress on the judicial system (Cooter and Rubinfeld (1989); Spier (1992); Perloff et al. (1996)) and compensates injured parties more timely (Fenn and Rickman (1999)).

A burgeoning law-and-economics literature has studied the roots of delay due to the litigation rather than the settlement of legal disputes. ${ }^{4}$ Less well understood is how long it takes parties to reach an agreement, and whether the legal system can have an influence on the duration of bargaining (Spier (1992), Fournier and Zuehlke (1996), Kessler (1996)). Using a novel data set from the Texas Department of Insurance (TDI) Commercial Liability Insurance Closed Claim Report, I present an empirical analysis of the determinants of settlement durations. Particular emphasis is placed on the durational effect of trial-court delays and statutes awarding prejudgment interest to prevailing plaintiffs. The latter imposes interest on damage awards to victorious plaintiffs from the time of injury until the date of judgment.

I structure the empirical analysis of bargaining by adapting Spier (1992)'s model of sequential pretrial negotiation where a defendant has private information about the level of damages that the plaintiff suffered. The defendant's liability is commonly known. Spier assumes that pretrial negotiation takes place over a finite period of time prior to a fixed trial date. In each period, the plaintiff makes an offer that the defendant may either accept or reject. If the litigants cannot reach an agreement then the case goes to trial. The way this model works is as follows: when the defendant has information that the plaintiff does not have, incentives are created for the former to credibly convey information to the latter; settlement delay occurs inevitably when the benefits of establishing credibility exceed the costs of bargaining. Spier's theory generates intuitive predictions that can be tested empirically: The duration of settlement increases with increases in the level of damages and the defendant's liability; The duration of settlement decreases with increases in the costs of continuing litigation.

I formulate hypotheses to explain how changes in the legal system and the bargaining environment affect the duration of settlement. I estimate reduced form empirical specifications which are based on the structural theoretical model. I present three major findings:

(a) I find that delay in trial courts reduces delay in settlement. This observation is consistent with a theoretic model where legal costs accumulate as litigation advances: Court delay increases the costs of continuing litigation thereby providing the litigants with a disincentive to prolong damage negotiation. Because the vast majority of claims are settled out-of-court, this result suggests that policies that streamline the court system by reducing trial-court delay will have the counter effect in most of the cases. ${ }^{5}$

\footnotetext{
${ }^{4}$ For excellent reviews of this literature, see Waldfogel (1998); Daughety and Reinganum (2005); and Spier (2007), (2008).

${ }^{5}$ Calculations (not explicitly reported in the table) based on the TDI data show that approximately $98 \%$ of bodily injury claims are resolved out-of-court.
} 
(b) Alternative dispute resolution (ADR) program, a substitute for trial, generates longer delays in settlements than non-ADR process, controlling for damage scale and other characteristics of claims. Spier's model offers a possible explanation for this observation: ADR reduces the litigants' transactions costs in reaching an agreement thereby providing the litigants with a greater incentive to delay agreement. This suggests that reform efforts aiming to cut cots may be partly or completely offset by a behavioral response to increase settlement duration.

(c) Consistent with the theory, higher prejudgment interest rates lead to longer delay in settlement, controlling for other institutional factors and the characteristics of claims. This is because prejudgment interest increases trial value thereby encouraging the plaintiff to pursue lengthy litigation. This result has important implications: Prejudgment interest laws designed to reduce delay do not work as intended; Were prejudgment interest abolished, settlements would be expedited substantially.

Robustness checks, based on alternative specifications and sample choices, provide further evidence of the unintended effect of the legal systems on settlement delays. Taken together, my sample of bodily injury claims finds that the duration of settlement negotiations consistently reflects the determinants suggested by the theory.

The empirical results presented here most closely relate to the important works of Kessler (1996) and Fournier and Zuehlke (1996), which study the effect of legal institutions on settlement delays. Kessler was the first to investigate the effect of the introduction of prejudgment interest law on settlement delay. Using data on automobile insurance bodily injury litigation, Kessler finds that settlement delay increases as a result of prejudgment interest law. Fournier and Zuehlke develop empirical specifications, based on Spier's theoretical analysis, of the causes of settlement delay. They find that fee shifting (i.e., changing from the American to the English rule for allocating legal fees ${ }^{6}$ ) causes a greater delay in settlement because fee shifting magnifies the effect of asymmetric information between parties to a legal dispute, making settlement more difficult. However, the empirical literature is ambiguous regarding the impact of trial-court delay: Kessler finds that delay in trial courts increases delay in settlement. But Fournier and Zuehlke find the opposite. ${ }^{7}$

This study contributes to this early body of work in that it resolves the ambiguous effect of trialcourt delay on settlement delay by taking as its starting point the comparative static results derived directly from a theoretical framework adapted from Spier (1992). I explicitly solve for the equilibrium of the bargaining game and characterize the effect of trial-court delay on settlement delay by closed form solutions. I then take the theoretical model to the large set of closed claim reports from 300 Texas counties over a 20-year span. I use these reports to construct measures of trial-court delay on a county-by-county and year-by-year basis. Semiparametric estimation techniques are then used to test whether disputes settled more quickly in judicial districts and years of longer trial-court delay. The

\footnotetext{
${ }^{6}$ In the U.S. legal system, each party pays their own legal expenses, regardless of the trial decision. In the English system, the loser pays the winner's legal expenses.

${ }^{7}$ Other related empirical work is that of Hersch et al. (2007) which uses the TDI data and Florida data to document the effect of early offer reform on settlement delays in medical malpractice cases. But Hersch et al. (2007) do not analyze the effect of trial-court delay on settlement delay.
} 
data consistently predict the effect suggested by the theory.

The model of settlement delay that is most similar to mine is Fenn and Rickman (2001), which focuses on the effects on settlement delay of bargaining environment such as the levels of damages, liability and costs in bodily injury insurance claims. They structure their empirical analysis by adapting Spier' model and assume that the plaintiff has private information about her damage and that the defendant's liability is commonly known. The estimated effects of damage and costs are as expected. But the estimates of liability, a key determinant of settlement delay in Fenn and Rickman's analysis, is inconsistent with the theoretical predictions. This result casts doubt on the validity of bargaining environment chosen by Spier (Fenn and Rickman (2001), page 628).

With its emphasis on institutional factors, my model of sequential pretrial negotiation differs from that of Fenn and Rickman. Moreover, the structure of my model differs from that of Fenn and Rickman in that I recognize an important feature of bodily injury insurance claims: defendants usually have private information about their liability while information on plaintiffs' damages could be obtained via discovery and independent medical examinations by either side. I adapt Spier (1992)'s information structure to model plaintiff's uncertainty about liability while maintaining the basic assumption of Spier's model that the defendant has private information about the (expected) trial outcome. ${ }^{8}$ I demonstrate the model's ability to reproduce many basic features of the data.

I believe that this study is the first cross-sectional econometric analysis of settlement delay. Where Kessler (1996), Fenn and Rickman (2001) and others have largely restricted their analysis to single insurance lines, the data I analyze cover a rich variety of insurance: general commercial, auto, multiperil, medical malpractice, and other professional liability. ${ }^{9}$ Cross-sectional variation as such could provide more robust identification. In particular, I find that medical malpractice and general liability claims settle more slowly than automobile liability claims. My determination of the degree to which settlement delay vary by insurance raises intriguing questions for policy makers. Are these differences due to different liability rules or to difference in insurance complexity? Policies that streamline the court system by altering liability rules and reducing the complexity of claims could reduce delay in settlement (Kessler (1996)). ${ }^{10}$

The rest of the paper is organized as follows. Section 2 describes the legal environment. Section 3 considers the theoretical foundation for empirical hazard models of the bargaining process. Section 4 describes the Texas Department of Insurance data and provides some summary information. Section 5 describes estimation methods. The empirical results are presented in section 6 , along with a series of robustness tests. Section 7 concludes.

\section{LEgAL ENVIRONMENT}

There are a number of characteristics of the legal system that can be studied in my framework.

\footnotetext{
${ }^{8}$ I am grateful to Kathryn Spier, Charles Silver, Bernard Black and Kowsar Yousefi for this suggestion.

${ }^{9}$ For example, Kessler (1996) and Fenn and Rickman (2001) study automobile liability cases. Hersch et al. restrict to medical malpractice. Fenn and Rickman (1999) restrict to medical negligence and employee cases but do not discuss the difference between them. Fournier and Zuelke (1996) examine delay using data on wide set of civil disputes but do discuss the difference in settlement behavior across case types.

${ }^{10}$ For instance, Kessler (1996) finds that comparative negligence reduces settlement hazard.
} 
The following three are of particular interest of the present analysis: (1) court delay, (2) prejudgment interest, and (3) alternative dispute resolution program.

$\square$ Court delay. Trial-court delay has been the central focus of serious and concentrated reform in the United States since the late-1950s. Common reform measures include, among others, increasing the number of trial judges, improving the management and administration of cases and changing the substantive law to simplify jury deliberation (Priest (1989)). Because courts demonstrably provide the ultimate resolutions to disputes, there is a natural tendency to use the speed of court proceedings as a measure of the time-efficiency of the court system.

However, the overwhelming majority of disputes are settled out-of-court (Farber and White (1991), Spier (1992), MacCoun (1991)) and many of them do so only until shortly before trials begin. But research to date has largely overlooked the impact of trial-court delay on settlement delay. ${ }^{11}$ There is a need for more theoretical and empirical analysis that studies the effect of trial-court delay on the timing of out-of-court settlements.

$\square$ Prejudgment interest. Most U.S. and European jurisdictions have adopted laws to impose interest on damage awards to prevailing plaintiffs from the time of injury until the date of judgment. Such interest is called prejudgment interest. ${ }^{12}$ Suppose $N$ is the number of days between the date of injury and the date of judgment, and $R$ is the statutorily imposed daily prejudgment interest rate. Then, by a prejudgment interest law, a defendant deemed liable for a damage of $\$ \pi$ in court will be required to pay the plaintiff $\$ \pi(1+R)^{N}$.

Legislators, courts and commentators favor these statutes partly because they believe that prejudgment interest expedites settlement out-of-court. ${ }^{13}$ The 'rationale' behind this law seems to be as follows: Suppose that the defendant refuses to settle early; if the court takes away from defendant the interest that he gains on damages that are unpaid but determined by court to be valid, disincentives will be created for the defendant to prolong litigation. ${ }^{14}$ Following this 'rationale', the prejudgment interest rates in Italy has doubled following the Italian civil justice reform of 1990. But little research has investigated the validity of this simple policy rationale because of lack of data on prejudgment interest laws and the impact of these laws. The relative dearth of research - both theoretical and empirical - makes prejudgment interest a ripe topic for further investigation. The TDI data provide a unique opportunity to examine the effect of prejudgment interest on settlement delay.

\footnotetext{
${ }^{11}$ The trial-court delay problem has been analyzed in a series of empirical studies. The early literature attributes trial-court delay to large caseload and understaffed court adopting poor case-management practice (Zeisel et al. (1959), Carrington (1969), Rosenberg (1965)). The latter studies suggest that long waits could be the outcome of voluntary behavior of key players of the litigation game such as the litigants and their lawyers (Nimmer (1978), Priest (1989), Kakalik et al. (1990)).

${ }^{12}$ Prejudgment interest law varies among jurisdictions in the US. Some states (e.g. Alaska and Georgia) set a fixed prejudgment interest rate by statute; others (e.g. Texas and Iowa) tie the rate to an established index. See Philips and Freeman (2003) for a survey across the U.S. states.

${ }^{13}$ Prejudgment interest statutes are also enacted to achieve "full compensation", on the grounds that a plaintiff with a valid claim should have been compensated for her damages immediately after the injury occurred.

${ }^{14}$ See, e.g., Pennsylvania Supreme Court (1981), Knoll (1996), Calhoun(1990), and Wilson et al. (1986), and Rubin and Shepherd (2007).
} 
$\square$ ADR. Mediation, arbitration, and other forms of alternative dispute resolution (ADR) programs are expected to reduce the transaction costs associated with reaching an agreement by providing an efficient substitute for trial. By design, ADR minimizes many expensive attributes of the litigation process, including jury selection, expert and witness testimony, and discovery (MacCoun (1990)). Moreover, ADR proceedings reduce the non-pecuniary costs to the litigants themselves (Spier (2007)). Several empirical results provide supportive evidence that ADR programs lead to significant cost reductions (e.g., Rosenberg and Folberg (1994)). ${ }^{15}$ However, current theory and empirical evidence suggest that such cost reductions could lead to prolonged delay in out-of-court settlement (Fournier and Zuehlke (1996), Fenn and Rickman (1999), (2001)). Furthermore, some ADR systems include fee-shifting provisions: if the litigant who rejected the ADR panel's decision receives a less favorable outcome at trial, then she has to pay her opponent's post-ADR litigation costs (Farber and White (1991), Spier (2007)). But fee-shifting could cause a greater delay in settlement by worsening the asymmetric information problems between the parties to a legal dispute (Fournier and Zuehlke (1996)).

Due to data limitations, this analysis side-steps the potential effect of fee-shifting provision in an ADR program. Instead, I focus on the cost differentials between ADR and non-ADR proceedings and their impact on the duration of settlement.

\section{THEORY}

Consider the following model of sequential bargaining which is adapted from the game analyzed in Spier (1992). A plaintiff has been injured in an accident. The plaintiff then files a lawsuit against the defendant. The plaintiff's damage, $\pi$, is commonly known. The plaintiff's case, if proceeded to trial, will be found meritorious with probability $\theta . \theta$ is determined by the level of the defendant's fault. The realized value of $\theta$ is known only to the defendant. ${ }^{16}$ This seems to be a reasonable assumption in the context of bodily injury claims where tortfeasors often have more knowledge regarding their negligence than the victims. Assume that the plaintiff has some subjective prior probability distribution for the unknown parameter $\theta$. For simplicity, let $\theta$ be uniformly distributed on $\left[\theta^{0}, \theta^{1}\right]$ (with $0<\theta^{0}<\theta^{1} \leq 1$ ).

Settlement bargaining takes place over $T$ periods. Trial takes place in period $T+1$ if litigants cannot agree. $T$ is determined by the scheduling availability of the court docket. Higher values of $T$ indicate longer trial-court delay and a longer time before a case can reach trial. ${ }^{17}$ The plaintiff makes all of the offers. ${ }^{18}$ In each period, $t$ (with $t \leq T$ ), the plaintiff makes a offer, $s_{t}$, which the defendant may either accept or reject. If she rejects, the game continues with the plaintiff making another offer in the following period. Let $R$ be the statutorily imposed prejudgment interest rate. In the event that

\footnotetext{
${ }^{15}$ See Spier (2007) for detailed description of the ADR procedures. For a somewhat more comprehensive review on the empirical analysis of ADR, see Kessler and Rubinfield (2004).

${ }^{16}$ Besides Spier (1992), P'ng (1983), Bebchuk (1984), Nalebuff (1987), Farber and White (1991) and Sieg (2000) make the same assumption that the defendant has private knowledge about the outcome at trial.

${ }^{17}$ Although counsel for either side can make requests on possible trial dates, the matter is up to the discretion of the trial judge. Therefore, assuming time-to-trial is exogenous to the litigants' decision seems to be reasonable.

${ }^{18}$ This assumption puts the whole bargaining power on the plaintiff's side, although generally the defendant may make counter offers. This assumption is made to avoid the multiplicity of equilibria associated with updating of beliefs. The timing of the dispute's resolution is robust to the order of offers or who make the offers in the negotiation process. See Spier (1992), page 97 and Zhou (2010), pp. 28-30.
} 


\begin{tabular}{|c|c|c|c|c|c|}
\hline & $t=0$ & $t=1$ & $t=\tilde{t}$ & $t=T$ & $t=T+1$ \\
\hline Accident & Plaintiff & Plaintiff offers $s_{1}$ & Plaintiff offers $s_{\tilde{t}}$ & Plaintiff offers $s_{T}$ & Trial \\
\hline & files lawsuit & $\begin{array}{l}\text { if defendant accepts, } \\
\text { then case settles; } \\
\text { if defendant rejects, then } \\
\quad \text { case goes to stage } 2\end{array}$ & $\begin{array}{l}\text { if defendant accepts, } \\
\text { then case settles; } \\
\text { if defendant rejects, } \\
\text { then case goes to } \\
\text { 'stage } \tilde{t}+1\end{array}$ & $\begin{array}{l}\text { if defendant accepts, } \\
\text { then case settles; } \\
\text { if defendant rejects, } \\
\text { then case goes to trial }\end{array}$ & $\begin{array}{l}\text { Court transfers } \\
\pi \text { from defenda- } \\
\text { nt to plaintiff } \\
\text { with prob. } \theta\end{array}$ \\
\hline
\end{tabular}

Figure 1. Diagram of Model Structure - Pretrial Negotiation

the case goes to trial, the court will transfer $\pi(1+R)^{T}$ from the defendant to the plaintiff with probability $\theta$.

The plaintiff incurs a cost $c$ (with $c>0$ ) at the beginning of each period and the litigants remain in conflict prior to the trial. ${ }^{19}$ In addition, the plaintiff incurs a cost $k$ (with $k>0$ ) if the case actually goes to court. The litigants discount time at the same rate; their discount factor is $\delta$ where $0<\delta<1$. The game is illustrated in Figure $1 .^{20}$

Let $s_{t}^{*}$ denote the offer in period $t$ in Perfect Bayesian Equilibrium (PBE) and let the upper bound of the distribution of types at the beginning of period $t$ be denoted $\theta_{t}$. The game has multiple equilibria. Following Spier (1992), I restrict to equilibria that satisfies the following property: The defendant's strategies are such that if type $\theta^{\prime}$ accepts settlement offer $s_{t}$ with positive probability, then all types $\theta^{\prime \prime}>\theta^{\prime}$ accepts $s_{t}$ with probability $1 .{ }^{21}$ Due to Spier, we have that if delay is costly but the costs of bargaining and trial are sufficiently small so that

$$
\left(\delta+\ldots+\delta^{T-1}\right) c+\delta^{T} k<\delta^{T}\left(\theta^{1}-\theta^{0}\right) \pi(1+R)^{T}
$$

then the PBE settlement offers are given by

$$
\begin{gathered}
s_{1}^{*}=\delta^{T}\left[\theta^{1} \pi(1+R)^{T}-k\right]-\sum_{i=1}^{T-1} \delta^{i} c \\
s_{t}^{*}=\delta^{1-t} s_{1}^{*}, \quad t=2, \ldots, T
\end{gathered}
$$

and the distribution of defendants remaining at the beginning of period $t$ is uniform on $\left[\theta^{0}, \theta_{t}\right]$, where:

$$
\theta_{1}=\theta^{1}
$$

\footnotetext{
${ }^{19}$ The plaintiff's attorney is usually paid on a contingency fee basis. We may interpret $c$ as the plaintiff's out-of-pocket expenses and value of time spent in bargaining and preparing for trial. The model can be easily generalized to include costs for the defendant as well. This extension comes at the expense of notation but hardly changes the results. See Spier (1989).

${ }^{20}$ The assumptions of a common discount factor and instantaneous trials are without loss of generality, because the effects of the trial-court delay, prejudgment interest and the bargaining environment on the settlement rate do not dependent on any of these factors.

${ }^{21}$ The assumption is made to guarantee that remaining distribution in each period is a truncation of the original distribution. The assumption is natural and has the benefit of simplifying proofs and providing strong intuition for the results. See Spier (1992), page 98.
} 


$$
\begin{gathered}
\theta_{t}=\theta^{1}-\frac{\sum_{i=1}^{t-1} \delta^{i} c}{\delta^{T} \pi(1+R)^{T}}, \quad t=2, \ldots, T-1 \\
\theta_{T+1}=\theta_{T}-k
\end{gathered}
$$

If condition (1) is violated, then

at period $t=1$ the plaintiff makes settlement offer $s_{1}^{*}=\delta^{T}\left[\theta^{0} \pi(1+R)^{T}-k\right]-\sum_{i=1}^{T-1} \delta^{i} c$, and

the defendant accepts regardless of her type.

Interpretation. The formal proofs of the results $(2)-(7)$ are similar to those in Spier (1992). ${ }^{22}$ Therefore, I omit them. But it is worth sketching the intuition, because the comparative statics of this model are fairly intuitive and could result quite reasonably from a variety of bargaining models. Inequality (1) suggests that prejudgment interest provides a plaintiff, who would otherwise settle immediately when the costs of bargaining and trial are high, with an incentive to delay settlement. This is because prejudgment interest increases the margin between the expected trial value and what the costs of delay would be. In each period the gains from settlement are the costs to be avoided in the subsequent periods. Therefore, when the costs of continuing litigation are high (i.e., when $T$ and $c$ are high), it benefits the plaintiff to raise the likelihood of settlement by making a low offer (equations (2) and (3)). High type defendants pay more in a trial than low type defendants and hence will settle early for higher damage payments, while low type defendants will be prepared to delay agreement until settlement offers drop $\left(\left\{\theta_{t}\right\}_{t=1}^{T}\right.$ is a decreasing sequence). Since in the last period the $\operatorname{costs} c$ are sunk, $\theta_{T}$ depends on $k$ but not on $c$ (equation (6)). The reason that the parties cannot do better by avoiding the inefficient delay and share the gains from early settlement is that there is no way for a low type defendant to "prove" that her chance of losing at trial is low except by going through a costly litigation.

From these results above, I derive the hypotheses that I will test empirically. They relate to the probability of settlement in period $t$ conditional on the event that settlement has not occurred earlier, i.e. the settlement hazard, $h(t ; \cdot)$. Due to (5), we have when (1) holds

$$
h(t ; T, R, c, \pi)=\frac{\theta_{t}-\theta_{t+1}}{\theta_{t}-\theta_{T}}=\frac{c(1-\delta) \delta^{t}}{\delta^{T}(1-\delta)\left[\left(\theta^{1}-\theta^{0}\right) \pi(1+R)^{T}-k\right]-c\left(\delta-\delta^{t}\right)}, \quad t=1,2, \ldots ., T-1 .
$$

By differentiation, we have

$$
\begin{gathered}
\frac{d h}{d T}>0 ; \quad \frac{d h}{d R}<0 ; \quad \frac{d h}{d c}>0 ; \quad \frac{d h}{d \pi}<0 ; \\
\frac{d h}{d t} \gtreqless 0 \Leftrightarrow \frac{\delta c}{\delta^{T}(1-\delta)}+k \gtreqless\left(\theta^{1}-\theta^{0}\right) \pi(1+R)^{T} .
\end{gathered}
$$

Interpretation. Inequalities (9) suggest that the hazard rate of settlement is increasing in the length of time to trial (as captured by the length of $T$ ) and the costs of delay (as captured by the magnitude of $c$ ) and decreasing in prejudgement interest rate (captured by the size of $R$ ) and the plaintiff's damage (captured by the size of $\pi$ ). The intuition underlying the comparative statics is as

\footnotetext{
${ }^{22}$ See Spier (1992), pp. 106-107.
} 
follows. Increases in trial-court delay and bargaining costs lead to an increase in the costs of continuing litigation. Therefore, the plaintiff has a greater incentive to settle early in a more congested and costly legal system. Further, increases in prejudgment interest and damages lead to an increase in the trial stakes thereby providing the plaintiffs with more incentive to pursue lengthy litigation. Moreover, Inequalities (10) suggests that the settlement hazard is increasing (resp. decreasing) over time when the costs of delay are high (resp. low) and the expected trial payment is low (resp. high).

The results above lead to the following hypotheses:

Hypothesis 1. The longer time that it takes for a case to reach a court verdict, the shorter is the duration of settlement.

Hypothesis 2. The duration of settlement increases with increases in prejudgment interest rate.

Hypothesis 3. The duration of settlement is longer in a legal process that is less costly.

Hypothesis 4. The duration of settlement increases with increases in the level of damages.

The model can also predict how changes in the legal system and bargaining environment affect the settlement hazard over time. Differentiating (8) twice, we have

$$
\begin{gathered}
\frac{\partial^{2} h}{\partial T \partial t} \gtreqless 0 \Leftrightarrow \frac{\delta c}{\delta^{T}(1-\delta)}+k \gtreqless\left(\theta^{1}-\theta^{0}\right) \pi(1+R)^{T} ; \\
\frac{\partial^{2} h}{\partial R \partial t} \lesseqgtr 0 \Leftrightarrow \frac{\delta c}{\delta^{T}(1-\delta)}+k \gtreqless\left(\theta^{1}-\theta^{0}\right) \pi(1+R)^{T} ; \\
\frac{\partial^{2} h}{\partial c \partial t} \gtreqless 0 \Leftrightarrow \frac{\delta c}{\delta^{T}(1-\delta)}+k \gtreqless\left(\theta^{1}-\theta^{0}\right) \pi(1+R)^{T} ; \\
\frac{\partial^{2} h}{\partial \pi \partial t} \lesseqgtr 0 \Leftrightarrow \frac{\delta c}{\delta^{T}(1-\delta)}+k \gtreqless\left(\theta^{1}-\theta^{0}\right) \pi(1+R)^{T} .
\end{gathered}
$$

Inequalities (11) - (14) mean that the effects of legal regime and the characteristics of bargaining environment on the settlement hazard may not be constant over time: With high costs, lengthy trial-court delays and less severe damages, the positive effects of court delay and bargaining costs on the settlement hazard increase as time elapses (inequalities (11) and (13)); and the negative effects of prejudgment interest and damages on the settlement hazard decrease as time elapses (inequalities (12) and (14)). Results (11) - (14) have important implications for the specification of empirical models to be discussed in Section 5 .

\section{DATA}

The data are from the Texas Department of Insurance (TDI) Commercial Liability Insurance Closed Claim Report (described in Hyman et al. (2007), (2008a), (2008b), Hersch and Viscusi (2007), Hersch et al. (2007) and Black et al. (2005), (2008)). Texas requires detailed reports for all claims for which the total damage payments by all insurers are at least $\$ 10,000$. A rich variety of case-specific information is recorded for the majority of claims, including the date of the injury and the dates for initiation, settlement and closure of the claims. These are the key variables of interest in this paper. 
TDI used two reporting forms: a "Short Form" for claims for which the damage payments for bodily injury are of $\$ 10,000-\$ 25,000$ (nominal), and a "Long Form" for claims for which damage payments for bodily injury are at least $\$ 25,000$ (nominal). The "Long Form" contains information on the nature of injury and victim's age and employment status that is omitted on the "Short Form".

Rules for inclusion in the sample. The TDI data include 213,179 paid claims over the years 1988-2008. I focus primarily on the period from August 1, 2003 to December 31, 2008, after Texas dramatically reduced the State's prejudgment interest rate. Roughly contemporaneous tort reforms include, among others, a cap on jury awards in medical malpractice lawsuits and a state wide early offer program that applies to all personal injury claims. ${ }^{23,24}$ Empirical evidence (Fournier and Zuehlke (1996), Fenn and Rickman (1999), (2001), Kessler (1996), Hersch et al. (2007)) suggests that each of these changes could expedite settlements. ${ }^{25}$ By restricting to the cases after August 1, 2003, the effect of prejudgment interest rates can be isolated from those of other institutional changes. Due to this restriction, 113,823 claims are dropped. In robustness checks, I obtain similar results using data for the period 1988 to July 2003 for the effect of trial-court delay and other variables. ${ }^{26}$

Secondly, I restrict the sample to "Long Form" reports because information on key variables, such as the nature of injury and victim's age and employment status, is missing from the "Short Form" ${ }^{27}$ Due to this restriction, 42,123 claims are dropped. Duplicate reports relating to the same underlying claim and reported in the same year further reduce the number of sampled observations. Because of these restrictions, the resulting sample of 54,760 claims contains 17,942 claims settled before court verdict in an ADR process and 36,818 claims settled before verdict in a non-ADR process. I refer to the sample of 54,760 cases as my bargaining sample.

Data limitations. My analysis is subject to at least three data limitations, and the results may best be interpreted with caution. The first limitation is that the TDI data set includes only paid claims. Therefore, I cannot analyze the duration of settlement on the universe of cases. ${ }^{28}$ Following an increase in prejudgment interest rate or reductions in legal costs and trial-court delay, victims may file some claims not currently brought that are not economically viable under the present tort regime. Because prejudgment interest increases delay by increasing the expected trial value, the estimates based on current claims data will serve as an upper bound of the impact of prejudgment interest and damages if there is a behavioral response leading to more claims compared with current claims levels.

\footnotetext{
${ }^{23}$ Calculations (not reported in tables) based on Texas Finance Code (2003 -2008) show that after August 2003 the prejudgment interest rate reduced by $50 \%$.

${ }^{24}$ Under the early offer program, a defendant facing a personal injury claim can offer to settle for full economic damages plus attorney fees, possibly with a minimum damages offer. A plaintiff who refuses the offer faces a higher burden of proof at trial.

${ }^{25}$ For example, Fournier and Zuehlke (1996), Fenn and Rickman (1999), (2001) and Kessler (1996) find that reduction in trial awards could lead to an increase in settlement hazards. Hersch et al. (2007) estimate that settlements will be expedited by the early offer program. Kessler (1996) reports evidence that imposing prejudgment interest on claims causes longer settlement delays.

${ }^{26}$ The descriptive statistics of claims of the period 1988-July 2003 are reported in the appendix. See Table 3 Panel C.

${ }^{27}$ Numerous previous research (see, e.g., Viscusi (1988), Rodgers (1993) and Avraham (2005)) has suggested that these variables are important determinants of damage award.

${ }^{28}$ For example, Dewees et al. (1996) estimate that 60 percent of medical negligence claims are closed without payment.
} 
The second limitation is that I do not have enough reliable information to identify and eliminate duplicate reports filed in different years. Identifying duplicates across different years necessarily requires information on the date of injury, victim's age, county, and claim amount paid by insurers contributing to the claim. Therefore, the success in finding all the duplicates is directly reliant on the accuracy of data provided by the insurance companies. When reports associated with the same underlying claim do not have the same injury dates, ages, or counties, it becomes difficult to ascertain the duplicates. ${ }^{29}$

The third limitation is that the TDI data does not contain detailed information on the ADR proceedings: First, a distinction between mediation, arbitration and other forms of proceedings is not made. Therefore, a comparative analysis could not be performed to gauge the difference or similarity in settlement dynamics between the different proceedings; Second, the data lack information on whether the ADR programs include fee-shifting provisions. As discussed in the introduction to this paper, fee-shifting could discourage settlement.

Settlement duration and stages of case disposition. The variables and model parameters are defined in Table 1, and the corresponding descriptive statistics are presented in Tables 2 and 3.

Panel A of Table 2 provides an overview for the bargaining sample of average settlement durations, by each of the five insurance policy types and by stages of disposition. Calculations (not explicitly reported in the table) based on the bargaining sample show that the overwhelming share of cases in the sample, $98.4 \%$, consists of claims settled before obtaining court verdicts.

DURATION refers to the number of months elapsed between the date that the insurer receives an claim and the date of claim closure. I say that settlement is delayed if a case's DURATION is positive. In robustness checks, I obtain similar results using months from injury to claim closure and months from suit filing to claim closure. The average DURATION of non-ADR settlements among claims in which no suit is filed are quite modest and range from an average of 13 months for other professional liability to 17 months for general liability. The average DURATION of ADR settlements among claims in which no suit is filed, reported in the second row of Table 2 Panel A, are considerable longer than non-ADR settlements without suit. Medical malpractice has the shortest average DURATION of 15 months. Auto liability, multiperil and other professional liability are about 27 percent greater, with DURATION around 19 months. The longest settlement delay is for general liability, with average DURATION of around 24 months.

Filing of lawsuit generates considerably longer settlement delays. For non-ADR pretrial settlements for claims for which a suit is filed, reported in the third row of Table 2 Panel A, general liability has the longest average DURATION of 33 months; auto liability and multiperil are not far behind, each with average DURATION around 31 months; The shortest delay is for other professional liability, with average DURATION of around 29 months. DURATIONs for non-ADR pretrial settlements with lawsuit are quite similar to those for ADR settlements with lawsuit and range from 29 months for medical malpractice and other professional liability to 31 months for general liability and auto liability.

\footnotetext{
${ }^{29}$ I am grateful to Vicky Knox at Texas Department of Insurance for pointing out this difficulty in verifying the accuracy of data for identifying duplicates.
} 
Table 1. Term and Variable Definitions

Definition

Claim ("case" is a synonym)

Settlement

DURATION

DURATION-1

DURATION-2

Legal System

COURT DELAY

COURT DELAY-1

RATE

ADR

BARGAINING ENVIRONMENT

POLICY LIMIT

EMPLOYED

AGE

MULTIDEF

INDIVDEF

Case Characteristics

INJURY

INSURANCE
An incident that leads to bodily injury and results in a request to an insurer(s) by a policyholder(s) for coverage.

Any form of non-court resolution or agreement that results in a termination of the claim. Settlement includes ADR settlement and non-ADR settlement.

The number of months from claim submission to claim closure.

The number of months from injury to claim closure.

The number of months from suit filing to claim closure.

Population mean of the number of months required to continue litigation until a trial judgment is obtained for cases in the same judicial district, stage of litigation and resolved in the same calender year.

For observations with reports on filing and trial dates, it equals the number of months required to reach trial from the time of filing; For observations with missing information on filing or trial dates, it equals the population mean of the number of months required to reach trial from the time of filing for cases in the same judicial district and resolved in the same calender year.

Statutory prejudgment interest rate in Texas for the years 1988-2008. The rate is $10 \%$ a year for claims resolved before August 2003. After August 2003, it equals the prime rate ('annual interest rate' is a synonym) of the Federal Reserve System with ceiling of 15 percent a year and floor of 5 percent a year.

Indicator with value 1 if the claim is resolved in an alternative dispute resolution process, 0 otherwise.

The maximum amount of damage payment a claimant(s) may recover in a single injury as laid down in the insurance policy document.

Indicator with value 1 if the plaintiff was employed, 0 otherwise.

Age of the plaintiff in years.

Indicator with value 1 if multiple defendants were involved, 0 otherwise.

Indicator with value 1 if the tortfeasor is an individual(s); 0 if the tortfeasor is an organization(s).

Categorical variable indicating the type(s) of injury associated with the claim. The injury types are fatality and serious nonfatal injuries (brain damage, spinal cord injury, and amputation). The omitted category is other nonfatal injuries.

Categorical variable indicating the line of insurance associated with the claim, including monoline general insurance, commercial auto liability, commercial multiperil liability, medical professional liability. The omitted category is auto liability. 
Table 2 Settlement duration by Insurance Policy Type and Stage of Disposition (in months)

Panel A: Means (standard deviations)

\begin{tabular}{|c|c|c|c|c|c|c|c|}
\hline Disposition of Claim & $\begin{array}{c}\text { Auto } \\
\text { liability }\end{array}$ & $\begin{array}{l}\text { General } \\
\text { liability }\end{array}$ & $\begin{array}{c}\text { Multiperil } \\
\text { liability }\end{array}$ & $\begin{array}{c}\text { Medical } \\
\text { malpractice } \\
\text { liability }\end{array}$ & $\begin{array}{c}\text { Other } \\
\text { professional } \\
\text { liability }\end{array}$ & $\begin{array}{c}\text { All } \\
\text { lines }\end{array}$ & Observations \\
\hline non-ADR settlement: no suit filed & $15(8)$ & $17(11)$ & $15(9)$ & $14(11)$ & $13(10)$ & $15(9)$ & 14,111 \\
\hline ADR settlement: no suit filed & $19(10)$ & $24(12)$ & $19(11)$ & $15(10)$ & $19(7)$ & $19(11)$ & 1,820 \\
\hline non-ADR: with suit, settled before trial & $31(14)$ & $33(17)$ & $31(16)$ & $30(15)$ & $29(15)$ & $31(15)$ & 22,177 \\
\hline ADR: with suit, settled before trial & $31(13)$ & $31(15)$ & $30(15)$ & $29(14)$ & $29(14)$ & $30(14)$ & 16,122 \\
\hline non-ADR: settled during trial, before verdict & $39(17)$ & $37(19)$ & $33(15)$ & $36(15)$ & $26(17)$ & $37(17)$ & 530 \\
\hline All stages of disposition & $24(14)$ & $29(16)$ & $27(16)$ & $29(15)$ & $26(15)$ & $26(15)$ & \\
\hline Observations & 28,190 & 9,977 & 6,752 & 9,276 & 565 & & 54,760 \\
\hline
\end{tabular}


TABLE 2 (Continued)

Panel B: Medians

\begin{tabular}{|c|c|c|c|c|c|c|c|}
\hline Disposition of Lawsuit & $\begin{array}{c}\text { Auto } \\
\text { liability }\end{array}$ & $\begin{array}{l}\text { General } \\
\text { liability }\end{array}$ & $\begin{array}{c}\text { Multiperil } \\
\text { liability }\end{array}$ & $\begin{array}{c}\text { Medical } \\
\text { professional } \\
\text { liability }\end{array}$ & $\begin{array}{c}\text { Other } \\
\text { professional } \\
\text { liability }\end{array}$ & $\begin{array}{c}\text { All } \\
\text { lines }\end{array}$ & Observations \\
\hline non-ADR settlement: no suit filed & 13 & 15 & 14 & 11 & 12 & 14 & 14,111 \\
\hline ADR settlement: no suit filed & 17 & 26 & 18 & 14 & 19 & 18 & 1,820 \\
\hline non-ADR: with suit, settled before trial & 29 & 31 & 29 & 27 & 28 & 29 & 22,177 \\
\hline ADR: with suit, settled before trial & 30 & 29 & 29 & 25 & 12 & 29 & 16,122 \\
\hline non-ADR: settled during trial, before verdict & 37 & 32 & 29 & 34 & 25 & 34 & 530 \\
\hline All stages of disposition & 22 & 27 & 24 & 25 & 24 & 24 & \\
\hline Observations & 28,190 & 9,977 & 6,752 & 9,276 & 565 & & 54,760 \\
\hline
\end{tabular}

SouRCE.- Author's calculations based on the Texas Department of Insurance Commercial Liability Insurance Closed Claim database for the period August 2003-2008 for claims with indemnity payments of at least $\$ 25,000$ in nominal value. Duplicate reports relating to the same incident in the same year are excluded; duplicate reports filed in different years are not identified and eliminated.

NoтE.- Durations reported in this table are the time elapsed between the date that a claim is reported to the insurer and the date of claim closure. 
Table 3: Descriptive Statistics

Panel A. Legal System and Bargaining Environment

\begin{tabular}{|c|c|c|}
\hline & Mean & Std. Dev. \\
\hline \multicolumn{3}{|l|}{ LEGAL SYSTEM } \\
\hline COURT DELAY (months) & 9.0 & 8.6 \\
\hline RATE (\%) & 5.67 & 1.2 \\
\hline $\operatorname{ADR}(1=$ yes $)$ & 0.33 & 0.47 \\
\hline \multicolumn{3}{|l|}{ BARGAINING ENVIRONMENT } \\
\hline POLICY LIMIT (\$) & $1,669,899$ & $4,203,512$ \\
\hline EMPLOYED (1=yes) & 0.61 & 0.49 \\
\hline AGE (years) & 41.5 & 18.7 \\
\hline MULTIDEF (1=yes) & 0.26 & 0.44 \\
\hline INDIVDEF (1=yes) & 0.13 & 0.33 \\
\hline Observations & \multicolumn{2}{|c|}{54,760} \\
\hline \multicolumn{3}{|c|}{$\begin{array}{l}\text { Note.- All dollar values are in } 2008 \$ \text {. The source for these values is author's calcu- } \\
\text { lations based on the Texas Department of Insurance Commercial Liability Insurance } \\
\text { Closed Claim database for the period August } 2003-2008 \text { for claims with indemnity pay- } \\
\text { ments of at least } \$ 25,000 \text { in nominal value. Duplicate reports relating to the same } \\
\text { incident in the same year are excluded; duplicate reports filed in different years are not }\end{array}$} \\
\hline
\end{tabular}

The problem of delay is particularly severe for cases settled after trial has started but before reaching a court verdict. The mean values of DURATION now exceed 3 years in three cases - auto liability, general liability and medical malpractice. The average DURATION for cases settled during trial is approximately 37 months. The level of DURATION for settlements during trial should be regarded as extreme outliers rather than the norm: In over 99 percent of the cases of the bargaining sample that settled before trial, the average level of DURATION is around 23 months.

DURATION for cases settled out-of-court averages 26 months across all insurance lines and all stages of disposition. Auto liability has the shortest DURATIOn, averaging 24 months. The longest settlement durations are for general liability and medical malpractice claims, each with an average DURATION of around 29 months. Table 2 Panel B reports the median values that correspond to the entries in Panel A. Because of the skewed distributions of the settlement durations, the median values are below the means in most of the instances.

Legal system, bargaining environment and case characteristics. Three sets of explanatory variables are employed in the analysis to account for possible variations in the trial outcomes and those in the costs of continuing litigation. A first set of variables captures aspects of the institutional environment where bargaining takes place. By far, the most important is COURT DELAY - the variable that measures the speed of court proceedings. I define (similar to Fournier and Zuehlke's (1996)) COURT DELAY as the average number of months required to continue litigation until a trial judgment is obtained for cases in the same judicial district, stage of litigation and resolved in the same calender year. ${ }^{30}$ Thus, COURT DELAY provides a district-year-specific measure of trial-court delay.

\footnotetext{
${ }^{30}$ Calculating COURT DELAY as the sample mean of months required to continue litigation until a judgment for claims reported in the same judicial district and the same year hardly alter the results.
} 
A second variable, RATE, controls for the magnitude of statutory prejudgment interest rate imposed on damage payment. For the bargaining sample, RATE equals to the prime rate ('annual interest rate' is a synonym) of the Federal Reserve System with ceiling of 15 percent a year and floor of 5 percent a year. ${ }^{31}$

A third legal system variable, ADR, indicates those cases settled by an alternative dispute resolution process. Due to the often complex effects of the ADR process, I do not construct a continuous measure of its effect but focus instead on a dummy variable categorizing whether the case is resolved by an ADR method. Approximately $33 \%$ of the cases in my sample are resolved by an ADR process.

A second set of variables reflect changes in the bargaining environment. The maximum amount of damage payment that is laid down in the insurance policy, POLICY LIMIT, provides a case specific measure of damages. Given the rarity of payments above limits, the variable may be used to account for the potential variations in damage levels. Limits are set before claims arise, so would be largely exogenous. The elasticity of damage payment with respect to POLICY LIMIT is estimated to be 0.138.

The two plaintiff characteristics, EMPLOYED and AGE, provide additional measures of damages. Damage award has two components: economic losses, consisting of wage loss and medical expenses, and noneconomic losses that are intended to compensate a victim for her pain and suffering. Employment income forms the basis for calculating the victim's wage losses. Pain and suffering that is permanent will be endured for a shorter period the older the victim is (Viscusi (1988)). Therefore, AGE could inversely reflect the duration of a victim's loss. Based on the TDI data for the years 1988-2004, Black et al. (2008) find that employed plaintiffs tend to receive more damage payments than unemployed ones and that damage payments for elderly victims plausibly fall short of payments for young victims. For the bargaining sample, the elasticities of damage payment with respect to EMPLOYED and AGE are estimated to be 0.175 and -0.061 , respectively.

MULTIDEF indicates cases that involve multiple defendants and is included to control for potential differences in the settlement decisions of multiple defendants. ${ }^{32}$ Approximately 32 percent of the cases in the bargaining sample involve multiple defendants. Fournier and Zuehlke's (1996) empirical evidence suggests that settlement takes longer to obtain when there are multiple litigants.

The next variable, INDIVDEF, is equal to one if the tortfeasor is an individual and zero if the tortfeasor is an organization. The variable is included to control for the potential difference in litigation strategies between individual and organization defendants. Eisenberg and Farber (1997) report evidence that individual litigants are more likely to go to trial than corporations. ${ }^{33}$ Approximately 13 percent of the cases in the bargaining sample involve individual tortfeasors. Calculations (not reported in the tables) based on the bargaining sample shows that damage claims against individuals are 5.7 times more likely to turn into lawsuits than those against organizations.

Finally, I include two categorical variables, InJuRY and InSURANCE, to control for the effects of omitted case specific characteristics that may be correlated with both settlement likelihood and the

\footnotetext{
${ }^{31}$ See Texas Office of Consumer Credit Commission (2007).

${ }^{32}$ The theoretic analysis discussed above do not consider the impact of the participation of multiple parties on settlement process. My purpose here is determine if there exist empirical differences in the duration of these cases relative to others.

${ }^{33}$ The theoretic analysis discussed above do not consider the impact of the individual versus organization defendants on settlement process. My purpose here is determine if there exist empirical differences in the duration of these cases relative to others.
} 
Table 3. (continued)

Panel B: Court Awards by Injury \& Insurance Types

\begin{tabular}{lrrr}
\hline \hline & Mean & Std. devn. & Observations \\
\hline INJURY & & & \\
Fatality $(\$)$ & $4,351,700$ & $3.49 \mathrm{e}+07$ & 370 \\
Serious nonfatal injuries & $4,345,233$ & $9,288,682$ & 202 \\
Other nonfatal injuries & 715,345 & 307,5790 & 1,998 \\
All types & $1,523,858$ & $1.38 \mathrm{e}+07$ & 2,570 \\
& & & \\
INSuRANCE & & & 1,052 \\
Auto liability (\$) & 691,325 & $2,137,418$ & 616 \\
General liability & $1,288,996$ & $4,111,447$ & 386 \\
Multiperil liability & $1,183,853$ & $4,008,986$ & 481 \\
Medical Malpractice & $3,767,910$ & $3.10 \mathrm{e}+07$ & 35 \\
Other professional liability & $3,582,643$ & $1.10 \mathrm{e}+07$ & 2,570 \\
All lines & $1,523,858$ & $1.38 \mathrm{e}+07$ & \\
\hline
\end{tabular}

Note.- All dollar values are in 2008 \$. The source for these values is author's calculations based on the Texas Department of Insurance Commercial Liability Insurance Closed Claim database for the years 1988-2008 for claims with indemnity payments of at least $\$ 25,000$ in nominal value. Duplicate reports relating to the same incident in the same year are excluded; duplicate reports filed in different years are not identified and eliminated.

included variables of interest. Table 3, Panel B reports the mean and standard deviation of court awards by different injury types and insurance lines. I report court awards for all tried cases from the population, not alone the tried cases in the sample period, to provide a comprehensive measure of the trial stakes for different injury and insurance types. The types of injury are characterized through a series of three injury categories, where the "other nonfatal injuries" group is the one excluded dummy variable. ${ }^{34}$ Fatality and serious nonfatal injuries types (amputation, brain damage and spinal cord injuries) have very high trial awards per claim with very high variation in awards across claims. Other nonfatal injury types such as back injuries and skin disorder have the opposite characteristics; these are frequently occurring injuries with very low trial awards per case and very small variation in awards across cases. Injury type is intended as a proxy for the severity of injury, on the assumption that injury types and seriousness are correlated.

The final variables to be considered are the types of insurance. They are characterized through a series of five insurance categories, where the "auto liability" group is the one excluded dummy variable. Auto liability is the most common insurance category. It has very low court awards per claim and very low variation in awards across claims. Medical malpractice, general liability and other professional liabilities have the opposite characteristics; these are infrequently occurring claims with very high damage awards per case and very large variation in awards across cases.

INJURY and INSURANCE are also potential measures of case complexity: Serious nonfatal injuries are usually more complex than fatal and other nonfatal injuries; Auto liability claims are usually less complex than other types of insurance claims such as medical malpractice and general liability.

\footnotetext{
${ }^{34}$ Hersch et al. (2007) adopted the same injury type classification.
} 


\section{The Empirical Models}

\subsection{Models of Settlement Duration}

To analyze the influence of legal regime and that of bargaining environment on the duration of settlements, hazard models were estimated. My focus here is the effect of each exogenous characteristic of the lawsuit on the probability of settlement, conditional on settlement not having already reached, and holding other case characteristics constant. The intervening endogenous settlement payment and actual litigation costs are not explicitly modeled.

In what follows, I estimate two alternative empirical specifications and investigate the robustness of the results. The second specification is a generalization of the first. It should be stressed that the empirical models I am using are reduced form models and not structural models.

- Cox's (1972) semiparametric proportional hazard model is the most popular approach towards characterizing the hazard function $h(t ; \cdot)$. The model is consistent with the empirical literature of dynamic pretrial bargaining ${ }^{35}$ and flexible enough to account for potential inappropriate distribution assumptions that may be involved in parametric methods. ${ }^{36}$ The hazard function for case $i$ is

$$
h_{i}\left(t ; \mathbf{x}_{i}\right)=h_{0}(t) \times \exp \left(\mathbf{x}_{i}^{\prime} \beta\right)
$$

where $t$ is the elapsed time since the start of bargaining, $\mathbf{x}_{i}$ is a vector of observed explanatory variables. The parameter vector $\beta$ is the vector of coefficients, measuring the influence of observed characteristics. The term $\exp \left(\mathbf{x}_{i}^{\prime} \beta\right)$ shifts the baseline hazard function $h_{0}(t)$, and a positive coefficient indicates that the observed case characteristics increase the settlement hazard and reduce the settlement duration. The model is semiparametric in that the baseline hazard $h_{0}(t)$ is a nonparametric function of time, with the influence of other observable case characteristics specified assuming a particular functional form. Furthermore, the model is a proportional hazard one since the ratio of the hazard function for any group with certain observed characteristics to that of the baseline hazard is equal to a constant, dependent only on the observed characteristics; i.e, $h(t) / h_{0}(t)$, the relative hazard function, is not time varying.

- Cox model with time varying effects of the covariates. To this point, our discussion of Cox model is fairly standard. Most applications make the baseline hazard rate a function of explanatory variables and estimate a single duration elasticity. However, it is important to consider the validity of the proportionality assumption. The results of section 3 (see inequalities (11) - (14)) suggest that changes in the bargaining environment and the legal system may not lead to strictly proportional shifts in the hazard function.

Consequently, I generalize, in a similar fashion as Fournier and Zuehlke (1998) and Fenn and Rickman (2001) do, the usual proportional hazard specification by allowing the duration elasticity of each observation to vary with the vector of explanatory variables. The model being estimated now

\footnotetext{
${ }^{35}$ See, e.g., Fenn and Rickman (2001) and Kessler (1999).

${ }^{36}$ The advantages of using Cox (1972) model to analyze time to event data have been widely recognized. See, e.g., Kalbfleisch and Prentice (1980), Meyer (1990), Kessler (1999) and Perperoglou (2005).
} 
takes the form of

$$
h_{i}\left(t ; \mathbf{x}_{i}\right)=h_{0}(t) \exp \left(\mathbf{x}_{i}^{\prime} \beta(t)\right) .
$$

where $h_{i}\left(t ; \mathbf{x}_{i}\right)$ is the hazard rate at time $t$ for case $i$ with covariates $\mathbf{x}_{i}$. Following Stablein et al. (1981), I assume that $\beta(t)$ is a vector of linear functions of time. This is equivalent to adding an interaction term of $\mathbf{x}$ and time to the model, which was proposed by Cox (1972) to check the assumption of proportional hazards for the covariates.

The value of adopting this specification follows directly from my comparative statics (11) - (14). This specification allows both the intercept and slope of the log-hazard function of cases to vary with changes in the legal system and bargaining environment.

Suppose that there are $n$ observations and $k$ distinct settlement times. Further suppose that I rank the settlement times such that $t_{1}<t_{2}<\ldots<t_{k}$ where $t_{j}$ denotes the settlement time for the $j$ th case. Furthermore, let $R_{j}$ denote the set of cases that have not settled until time $t_{j}$. Then the probability that the $\ell$ th case will settle at time $t_{j}$ given that some case in set $R_{j}$ will settle at time $t_{j}$ is

$$
\frac{h_{\ell}\left(t_{j} ; \mathbf{x}_{\ell}\right)}{\sum_{\tau \in R_{j}} h_{\tau}\left(t_{j} ; \mathbf{x}_{\tau}\right)}=\frac{\exp \left(\mathbf{x}_{\ell}^{\prime} \beta\left(t_{j}\right)\right)}{\sum_{\tau \in R_{j}} \exp \left(\mathbf{x}_{\tau}^{\prime} \beta\left(t_{j}\right)\right)}
$$

Taking the product of the conditional probabilities in (16) yields the partial likelihood function

$$
\mathcal{L}=\prod_{j=1}^{k}\left[\frac{\exp \left(\mathbf{x}_{j}^{\prime} \beta\left(t_{j}\right)\right)}{\sum_{\tau \in R_{j}} \exp \left(\mathbf{x}_{\tau}^{\prime} \beta\left(t_{j}\right)\right)}\right],
$$

with corresponding log-likelihood function

$$
\ln \mathcal{L}=\sum_{j=1}^{k}\left[\mathbf{x}_{j}^{\prime} \beta\left(t_{j}\right)-\ln \sum_{\tau \in R_{j}} \exp \left(\mathbf{x}_{\tau}^{\prime} \beta\left(t_{j}\right)\right)\right] .
$$

For the proportional hazard model where a single duration elasticity is estimated, $\beta\left(t_{j}\right)=\beta$ for all $j \in\{1,2, \ldots, k\}$.

\section{EMPIRICAL EvidENCE}

\subsection{Duration of Settlement}

- Graphical analysis. I begin by graphing the non-parametric Kaplan-Meier hazard functions over the first 70 months of claim open for different factors that could influence the duration of settlement. The empirical hazard is the fraction of unsettled claims at the start of a month which settle during the month. ${ }^{37}$ These functions plot rates of settlement against the settlement durations.

Figures 2, 3 and 4 depict the settlement hazards stratified by different institutional factors. Settlement hazards in counties with longer trial-court delays are apparently higher than those in less congested court systems during the first 50 months of claim open (Figure 2). The pattern is reversed, however, as bargaining advances. Increasing the prejudgment interest rate from below 5 percent to

\footnotetext{
${ }^{37}$ Formally, defining the risk set in month $m, R_{m}$, as the number of claims not settled by the start of month $m$, and the number of settlements in month $m$ as $S_{m}$, the Kaplan-Meier empirical hazard is defined as $S_{m} / R_{m}$.
} 


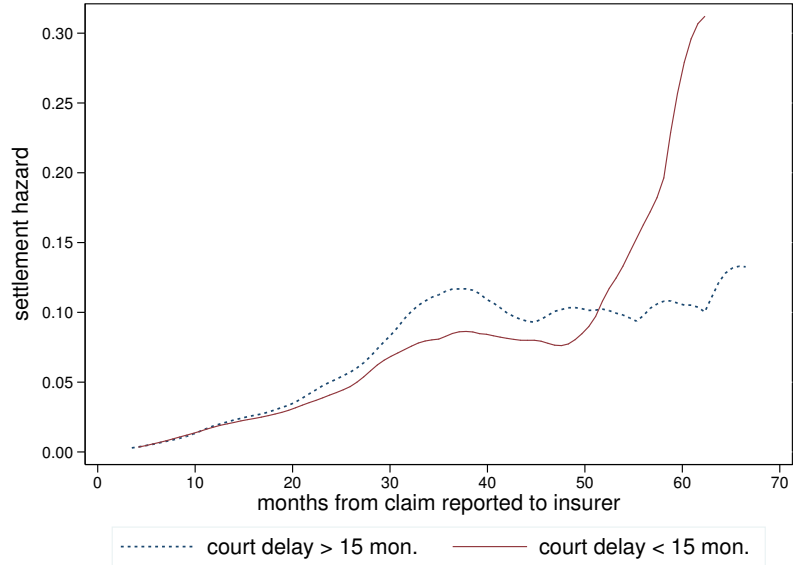

Figure 2: Effect of Trial-Court Delay

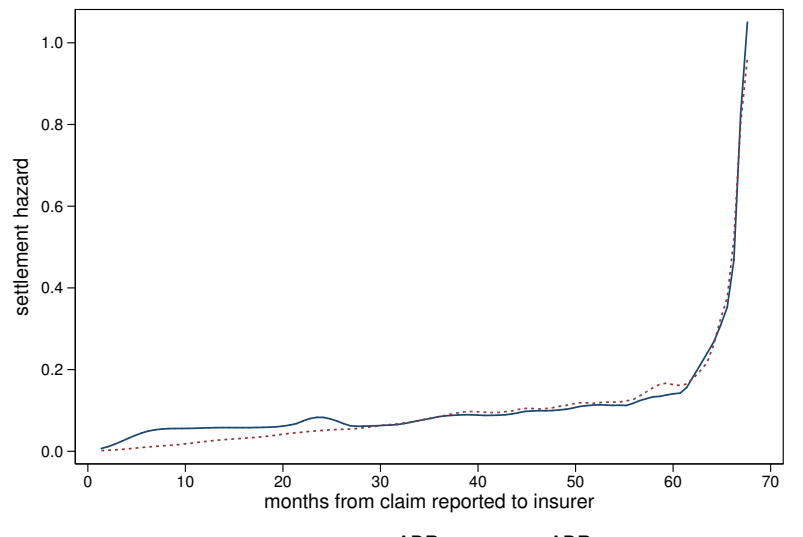

Figure 4: ADR vs. non-ADR Processes

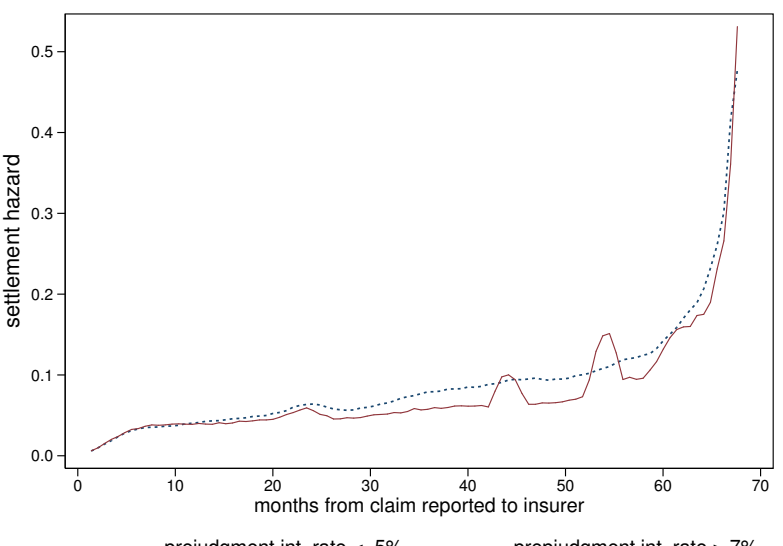

Figure 3: Effect of Prejudgment Interest

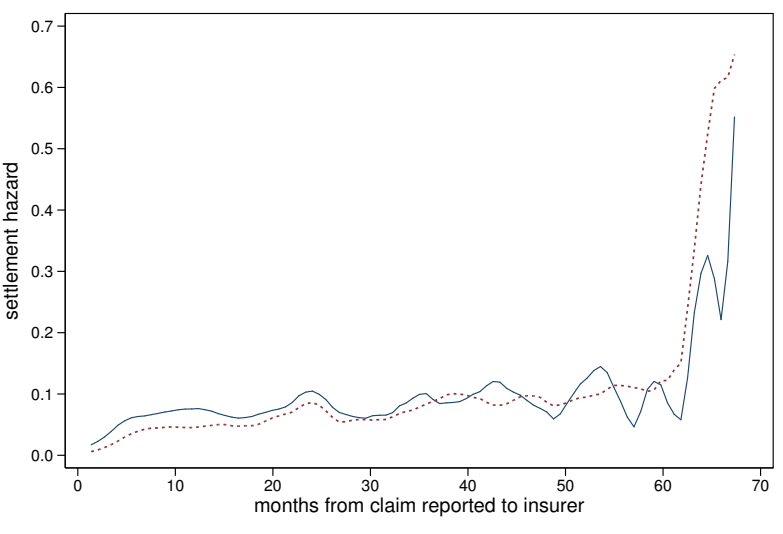

Figure 5: Settlement Hazard by Policy Limit

above 7 percent results in a hazard profile with a lower probability of settlement during most of the course of settlement negotiation (Figure 3). ADR reduces the rapidity of settlement during approximately the first 30 months after the insurer receives the damage claim. But the impact of ADR becomes less obvious as litigation prolongs (Figure 4). These graphical analyses suggest that the effect of the legal regimes suggested by the theory may be a reasonable approximation to actual impact. But the effect of legal system may not be constant over time. I explore these conjectures more rigorously in the next section.

Figure 5 plots the sample hazards stratified by insurer's policy limits. Increasing the policy limits from below $\$ 100,000$ to over $\$ 1,000,000$ results in a hazard profile with a lower probability of settlement for approximately 37 months. This pattern becomes less pronounced, however, as litigation prolongs. This graphical analysis suggests that there may be a systematic relation between settlement duration and damage scale.

Figures 6 and 7 present the estimated impact of plaintiff characteristics on the settlement hazard. Figure 6 displays a tendency for elderly plaintiffs to settle earlier than young plaintiffs during most of the time course of negotiation. Moreover, this tendency becomes more pronounced as litigation advances. This result can be interpreted as follows: high damages (as controlled by the age of the victim) discourage settlement and the magnitude of the disincentive increases with the duration of settlement. There is no apparent difference in settlement hazards between employed and unemployed 


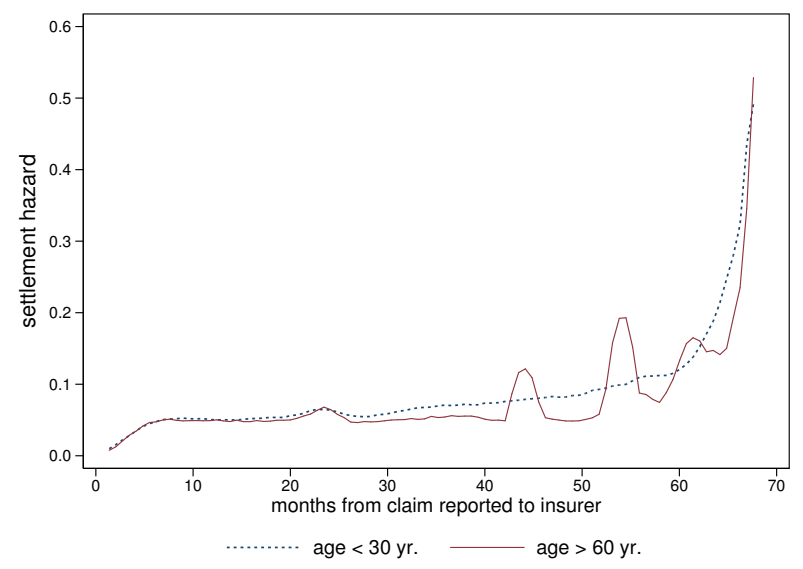

Figure 6: Settlement Hazard by Plaintiff Age

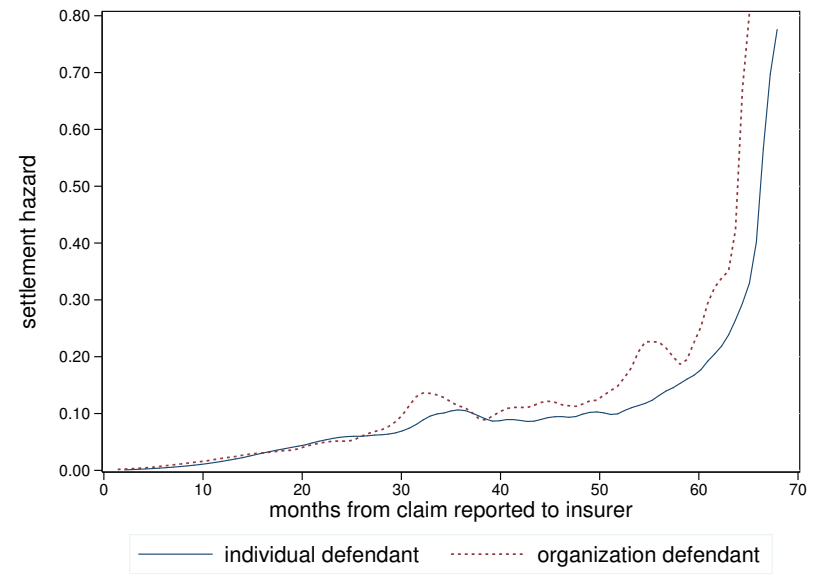

Figure 8: Individual vs. Organization Defendants

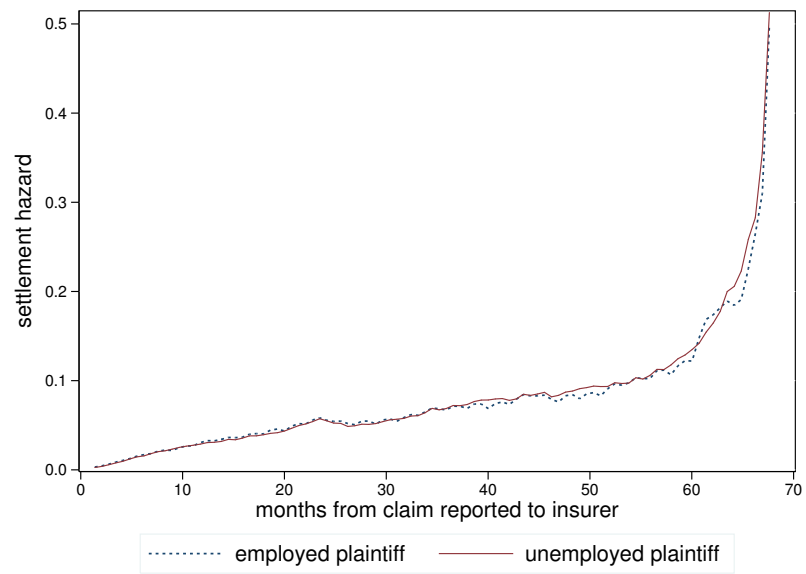

Figure 7: Settlement Hazard by Employment

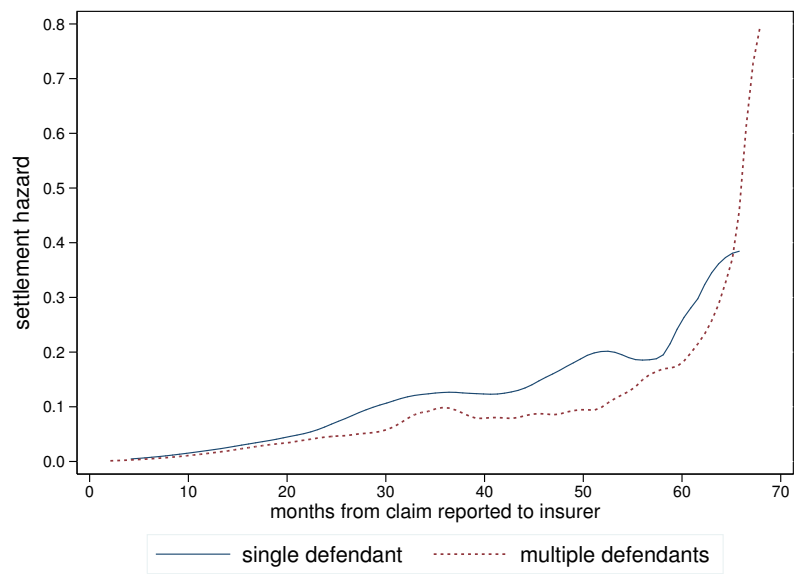

Figure 9: Single vs. Multiple Defendants

plaintiffs (Figure 7).

A caveat to the analysis in Figures 5, 6 and 7 is that it might not provide an adequate impression of the impact of damages: The theory presented in section 3 suggests that settlement hazards tend to decrease with damages and increase with costs. ${ }^{38}$ However, high damages are usually associated with high legal expenditures. ${ }^{39}$ Since the analysis in Figures 5, 6 and 7 does not single out the effect of damage from that of costs, the effect of damage is likely to be underestimated.

Figures 8 and 9 illustrate the estimated impact of defendant characteristics on the settlement hazard. Cases involving individual tortfeasors have lower settlement hazards and therefore take longer to resolve (Figure 8). Single defendant claims settle faster than multiple defendants claims (Figure 9). Taken together, these graphical analyses suggest that the characteristics of the defendants are clearly associated with the timing of dispute resolution.

Figure 10 provides a snapshot of the settlement hazards stratified by the nature of injury. Claims involving serious and complex nonfatal injuries (brain damage, spinal cord injury, and amputation) take longer to settle than other nonfatal injuries. Fatalities have lower settlement hazards than nonfatal injuries during the first 30 months after the insurer receives the claim. This pattern is reversed,

\footnotetext{
${ }^{38}$ Fenn and Rickman (2001) and Fournier and Zuehlke (1996) make the same prediction that settlement hazards increase with the severity of damage and decrease with the level of legal costs.

${ }^{39} \mathrm{~A}$ regression of damage payout on total defense expenses for all claims reported to the TDI from 1988 to 2008 yields a coefficient of $1.68(p$-value $=0.000)$ and an $R$-squared of 0.03 .
} 


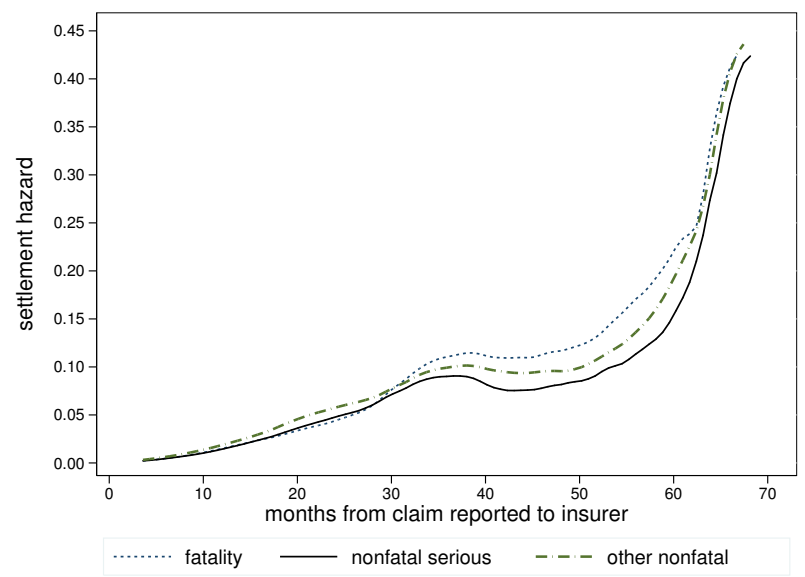

Figure 10: Settlement Hazard by Injury Severity

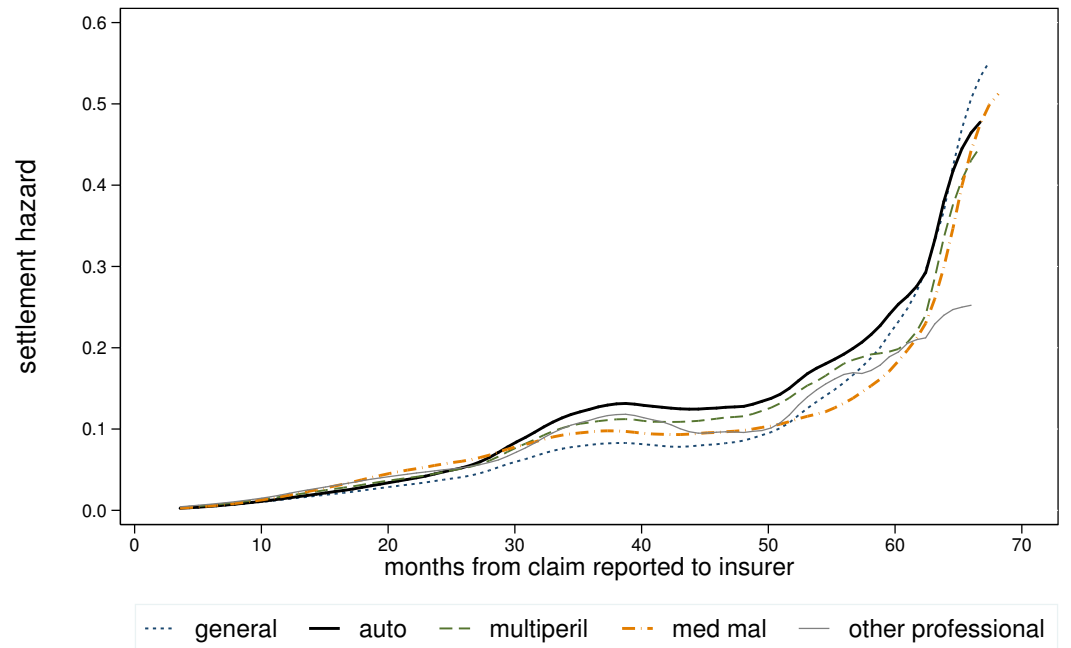

Figure 11: Settlement Hazard by Type of Insurance

however, as litigation prolongs. This graphical analysis suggests that the severity and complexity of injury clearly affect the settlement hazard but their effects vary over time.

Figure 11 plots the sample hazards for insurance of different types. There is a clear marked variation across types after approximately 27 months from the initiation of a claim: The settlement hazards are much higher for auto liability claims than for general liability and medical malpractice claims. Table 2, together with this figure clearly indicate that the pattern of settlement delays differ considerably across insurance lines.

- Regression analysis. Table 4 reports the Cox regression estimates of the time-dependence coefficients and the baseline coefficients. ${ }^{40}$ Both specifications reported make the baseline $(t=1)$ hazard rate a function of the case characteristics discussed in Section 3. The specifications differ in their treatment of the duration elasticity. The specification reported in the first column is rather simple, allowing the initial hazard rate a function of explanatory variables but estimating a single duration elasticity. The specification in the second column generalizes the first model by making the duration

\footnotetext{
${ }^{40}$ The continuous variables are in terms of natural logs so that the coefficients in the equation equals the duration elasticities of the hazard rate with respect to the independent variables. In addition, I add one to all values before taking natural logs because some claims report zero values.
} 
Table 4. Cox Regression Parameter Estimates of The Bargaining Sample (54,760 observations)

\begin{tabular}{|c|c|c|}
\hline & Log(DURATION) & Log(DURATION) \\
\hline \multicolumn{3}{|l|}{ Baseline Parameters } \\
\hline \multirow[t]{2}{*}{ Log(COURT DELAY) } & $0.193^{* *}$ & $0.727^{* *}$ \\
\hline & $(0.004)$ & $(0.022)$ \\
\hline \multirow[t]{2}{*}{$\log (\mathrm{RATE})$} & $-0.175^{* *}$ & $-0.200^{\dagger}$ \\
\hline & $(0.024)$ & $(0.121)$ \\
\hline \multirow[t]{2}{*}{$\mathrm{ADR}$} & $-0.215^{* *}$ & $-1.879^{* *}$ \\
\hline & $(0.009)$ & $(0.054)$ \\
\hline \multirow[t]{2}{*}{ Log(POLICY LIMIT) } & $-0.041^{* *}$ & $-0.303^{* *}$ \\
\hline & $(0.005)$ & $(0.022)$ \\
\hline \multirow[t]{2}{*}{ EMPLOYED } & $-0.034^{* *}$ & -0.054 \\
\hline & $(0.009)$ & $(0.047)$ \\
\hline \multirow[t]{2}{*}{$\log (\mathrm{AGE}+1)$} & $0.054^{* *}$ & 0.001 \\
\hline & $(0.006)$ & $(0.031)$ \\
\hline \multirow[t]{2}{*}{ MULTIDEF } & $-0.159^{* *}$ & $-0.148^{* *}$ \\
\hline & $(0.011)$ & $(0.011)$ \\
\hline \multirow[t]{2}{*}{ INDIVDEF } & $-0.059^{*}$ & $-0.044^{\dagger}$ \\
\hline & $(0.023)$ & $(0.023)$ \\
\hline \multirow{2}{*}{ Nonfatal Serious Injuries } & $-0.069^{* *}$ & $-0.477^{* *}$ \\
\hline & $(0.018)$ & $(0.099)$ \\
\hline \multirow[t]{2}{*}{ Fatality } & $-0.029^{*}$ & -0.081 \\
\hline & $(0.013)$ & $(0.066)$ \\
\hline \multirow[t]{2}{*}{ General Liability } & $-0.211^{* *}$ & $-0.199^{* *}$ \\
\hline & $(0.012)$ & $(0.012)$ \\
\hline \multirow[t]{2}{*}{ Multiperil Liability } & $-0.075^{* *}$ & $-0.063^{* *}$ \\
\hline & $(0.014)$ & $(0.014)$ \\
\hline \multirow[t]{2}{*}{ Med Mal } & $-0.111^{* *}$ & $-0.092^{* *}$ \\
\hline & $(0.022)$ & $(0.022)$ \\
\hline \multirow[t]{2}{*}{ Other Professional Liability } & -0.033 & -0.023 \\
\hline & $(0.043)$ & $(0.043)$ \\
\hline \multicolumn{3}{|l|}{ Time-Dependence Parameters } \\
\hline \multirow[t]{2}{*}{ Log(COURT DELAY) } & & $-0.168^{* *}$ \\
\hline & & $(0.007)$ \\
\hline \multirow[t]{2}{*}{$\log (\mathrm{RATE})$} & & 0.005 \\
\hline & & $(0.038)$ \\
\hline \multirow[t]{2}{*}{$\mathrm{ADR}$} & & $0.524^{* *}$ \\
\hline & & $(0.016)$ \\
\hline \multirow[t]{2}{*}{ Log(POLICY LIMIT) } & & $0.086^{* *}$ \\
\hline & & $(0.009)$ \\
\hline \multirow[t]{2}{*}{ EMPLOYED } & & 0.007 \\
\hline & & $(0.007)$ \\
\hline \multirow[t]{2}{*}{$\log (\mathrm{AGE}+1)$} & & $0.016^{\dagger}$ \\
\hline & & $(0.009)$ \\
\hline \multirow[t]{2}{*}{ Nonfatal Serious Injuries } & & $0.128^{* *}$ \\
\hline & & $(0.030)$ \\
\hline \multirow[t]{2}{*}{ Fatality } & & 0.018 \\
\hline & & $(0.020)$ \\
\hline
\end{tabular}

Log likelihood

$-542,932.51$

$-541,927.79$

Note.- Standard errors are shown in parentheses. $\dagger$ significant at 10 percent level; ${ }^{*}$ significant at 5 percent level; ** significant at 1 percent level. Omitted injury type is other nonfatal injuries. Omitted insurance policy type is auto liability. The source for these values is author's calculations based on the Texas Department of Insurance Commercial Liability Insurance Closed Claim database for the period August 2003-2008 for claims with indemnity payments of at least $\$ 25,000$ in nominal value. Duplicate reports relating to the same incident in the same year are excluded; duplicate reports filed in different years are not identified and eliminated. 
elasticity a function of the legal system variables and bargaining environment variables. This specification allows me to determine whether there is empirical support for the propositions obtained from my comparative static analysis of Spier's model (inequalities (11) - (14)). Particularly, do the settlement hazards of claims increase or decrease with changes in the institutional environment?

For the simpler specification, reported in column 1 of Table 4, the significantly positive sign of the coefficient of COURT DELAY suggests that delay in trial courts reduces delay in out-of-court settlement - a result in line with my theoretical prediction. A one percentage point increase in trial-court delay would increase the settlement hazard by 21 percent. ${ }^{41}$ The estimated duration elasticity of RATE is significantly negative. This indicates that cases with higher prejudgment interest rates take longer to settle.

The coefficient of ADR cases is significantly negative. This suggests that ADR process reduces the rapidity of settlement. One caveat to this interpretation is raised by the potential endogeneity of ADR process. My model cannot determine whether the empirical differences attributed to the ADR process reflect the impact of such a process on settlement behavior, or simply the underlying characteristics that led the litigants to resolve their dispute in an ADR process. ${ }^{42}$

Spier's model predicts that the time path of the hazard function shifts downwards with increases in the level of damage awards. The baseline coefficients in the first model are generally consistent with this proposition. Cases with high policy limits tend to settle more slowly than cases with low limits because policy limits reflect the magnitude of damages. Cases involve employed and young claimants tend to settle more slowly than cases involve unemployed and elderly claimants because damage awards for unemployed and elderly victims tend to fall short of awards for employed and young ones. The significantly negative coefficients of "fatality" and "nonfatal serious injuries" provide a result that is consistent with one's expectations and early evidence (Kessler (1996)): more severe injuries take longer to settle, ceteris paribus.

Moreover, the significantly negative coefficients of INDIVDEF and MULTIDEF suggest a clear link between settlement delay and the type and the number of defendants: Cases involve individual defendants settle more slowly than cases involve organization defendants; Settlement is more difficult to obtain when there are multiple litigants. ${ }^{43}$

Finally, it should be noted that the character of insurance is consequential. In particular, claims associated with less routine and more complex insurances take longer to settle. The settlement hazard of auto liability claims is approximately 20 percent $(\exp \{0.211\}-1 \approx 20 \%)$ higher than that of general liability, 8 percent $(\exp \{0.075\}-1 \approx 8 \%)$ higher than that of multiperil liability and 10 percent $(\exp \{0.111\}-1 \approx 10 \%)$ higher than that of medical malpractice.

One shortfall of the first specification in Table 4 is that attribute variation, to the extent it has any impact, is constrained to generate parallel shifts in the log-hazard function. The baseline coefficients reported above determine intercept shifts in the linear relationship between the log-hazard function

\footnotetext{
${ }^{41} \exp \{0.193\}-1 \approx 21 \%$

${ }^{42}$ Deleting ADR from the regression hardly change the estimates of other parameters in the model.

${ }^{43}$ Kornhauser and Revesz (1994) show that cases associated with multiple defendants who share joint and several liability have lower likelihood of settlement when the plaintiffs' probabilities of trial success are sufficiently uncorrelated across cases.
} 
and the log of current duration. The generalized model reported in column 2 of Table 4 allows variation in legal system and case scale to change both the intercept and slope of this linear relationship. The coefficients reported under the heading Time-Dependence Parameters gauge the effect of changes in institutional and case scale on the slope, or duration elasticity, of this linear relationship.

As in the first model, the baseline coefficient of COURT DELAY is positive, statistically significant and greater than the corresponding estimate from the simpler model. In contrast to its baseline effect, the time-dependence coefficient of COURT DELAY is significantly negative. This result might best be interpreted as follows: Trial-court delay increases the settlement hazard shortly after the claim is reported to the insurer but decreases the hazard long after the claim is reported. Since the timedependence effect is small relative to the baseline effect, however, the former does not overcome the latter within the sample range. ${ }^{44}$

There is a similar pattern associated with RATE where the baseline and time-dependence effects work in opposition. The net effects, judged within the observed range of duration, are consistent with the theory (see inequalities (9)). The baseline coefficient of RATE is negative and greater in absolute value than the corresponding estimate from the simpler model. The time-dependence coefficient of RATE is positive but small relative to its baseline coefficient, and it is statistically insignificant. Consequently, a unit increase in RATE shifts the hazard profile downwards over the relevant range of the data. ${ }^{45}$

Further, it should be noted that the method of dispute resolution is consequential. The baseline coefficient of ADR is negative and statistically significant in the generalized model. The time-dependence coefficient of ADR is positive and statistically significant. Thus, alternative dispute resolution results in a log-hazard profile with a smaller intercept and a greater slope. The unexpected time-dependence effect of ADR, however, does not overcome the baseline effect until claim duration exceeds approximately 36.1 months $(\exp \{1.879 / 0.524\} \approx 36.1)$. Only $9 \%$ of the bargaining sample consists of ADR-cases with duration exceeding 36.1 months. Therefore, the hazard rate of non-ADR cases eventually overtakes that of ADR cases in a relatively small fraction of instances. These results might best be interpreted as follows: ADR discourages early settlement, but the magnitude of the disincentive diminishes with the duration of settlement.

Turning to my measures of damages, the baseline coefficient of POLICY LIMIT is negative, statistically significant, and much larger in absolute value than that in the simpler model. Its estimated timedependence coefficient is positive and statistically significant, but small and dominated by the large negative effect of the baseline parameter. Thus, an increase in POLICY LIMIT results in a log-hazard profile with a significantly smaller intercept and a greater slope. The time-dependence effect of an increase in POLICY LIMIT overcomes the baseline effect slowly. A unit increase in POLICY LIMIT results in a lower hazard profile of settlement for approximately 33.9 months, encompassing 72 percent of the sampled claims.

The baseline and time-dependence coefficients of EMPLOYED, my second measure of damages, are

\footnotetext{
${ }^{44}$ The time-dependence effect of COURT DELAY does not overcome the baseline effect until duration exceeds approximately $146(\exp \{0.727 / 0.168\} \approx 75.8)$ months, encompassing all of the sampled claims.

${ }^{45}$ The time-dependence effect of RATE does not overcome the baseline effect until duration exceeds approximately $2.35 \times 10^{17}\left(\exp \{3.31 / 0.664\} \approx 2.35 \times 10^{17}\right)$ months, encompassing all of the sampled claims.
} 
negative but statistically insignificant. The baseline coefficient of $\log (\mathrm{AGE}+1)$, my third (reverse) measure of damages, is positive but statistically insignificant. As one would expect, the time-dependence coefficient of $\log (\mathrm{AGE}+1)$ is significantly positive. Because damages tend to decrease with increases in claimant age, this result suggests that the hazard rate is negatively correlated with the level of damages.

The injury variables reflect both case complexity and the scale of the claim. The estimated effects of injury types on the settlement hazards are economically plausible. The significantly negative baseline coefficient of "nonfatal serious injuries" suggests that claims based on nonfatal serious injuries take longer to settle than other nonfatal injuries shortly after a claim is submitted to the insurer. The significantly positive time-dependence coefficient suggests that the pattern is reversed long after the claim is submitted. Since the time-dependence coefficient is small relative to the baseline coefficient, however, it follows that for nonfatal harms the complexity and severity of damage increase delay in aggregate. ${ }^{46}$ Unlike in the simpler model, however, the settlement hazard of fatality is not significantly different from that of other nonfatal injuries.

The baseline and time-dependence coefficients of the defendant characteristics variables and the insurance type variables reported in column 2 are all quantitatively and qualitatively similar to those reported in the column 1 . These coefficients require no additional discussion.

\subsection{Robustness Checks}

In this section I briefly describe exercises I conducted to see if the results above are robust to my empirical modeling assumptions. Four robustness concerns are addressed. They relate to (1) alternative settlement duration measures, (2) alternative trial-court delay measure, (3) the effect of legal institution on settlement duration in different insurance lines and (4) alternative sample period.

\section{A. Alternative Settlement Delay Indicators}

The previous subsections reveal a significantly impact of court delays, prejudgment interest, and dispute resolution mechanism on settlement durations measured as the time elapsed between the date that the insurer receives the claim and the date of case termination. In this subsection, I investigate the robustness of these finding to the use of alternative measures of settlement delays: the time elapsed between injury and case termination and [2] the time elapsed between filing and case termination for claims in which a suit is filed.

I rerun the model in column 2 of Table 4 for each settlement duration indicators. Estimates of the baseline coefficients and the time-dependence coefficients are presented in columns 1 and 2 of Table 5. It turns out that both duration measures are affected in similar ways by the legal institutions to that of DURATION. An exception is that the coefficients of RATE are not significant at conventional level in the model reported in column 1 of Table 5 . This is in part because the time between injury and claim closure does not provide as accurate a measure of settlement duration as the time between claim submission and claim closure: There is considerable variation in the time elapsed between injury and

\footnotetext{
${ }^{46}$ The time-dependence effect of nonfatal serious injuries does not overcome the baseline effect until duration exceeds approximately $41.5(\exp \{0.477 / 0.128\} \approx 41.5)$ months, encompassing 84 percent of the sampled claims.
} 
Table 5. Robustness Checks: Alternative Settlement Duration and Court Delay Indicators

\begin{tabular}{|c|c|c|c|}
\hline & $\begin{array}{l}\text { Time between } \\
\text { Injury \& Closure } \\
(N=54,760)\end{array}$ & $\begin{array}{c}\text { Time between } \\
\text { Filing \& Closure } \\
\quad(N=38,829)\end{array}$ & $\begin{array}{l}\text { Time Between } \\
\text { Claim \& Closure } \\
(N=54,760)\end{array}$ \\
\hline Variable & $\begin{array}{c}\text { Log } \\
\text { (DURATION-1) }\end{array}$ & $\begin{array}{c}\text { Log } \\
\text { (DURATION-2) }\end{array}$ & $\begin{array}{c}\text { Log } \\
(\text { DURATION) }\end{array}$ \\
\hline \multicolumn{4}{|l|}{ Baseline Parameters } \\
\hline Log(COURT DELAY) & $\begin{array}{c}0.935^{* *} \\
(0.024)\end{array}$ & $\begin{array}{c}0.217^{* *} \\
(0.022)\end{array}$ & - \\
\hline Log(COURT DELAY-1) & $\begin{array}{l}- \\
-\end{array}$ & - & $\begin{array}{l}0.494^{* *} \\
(0.088)\end{array}$ \\
\hline $\log (\mathrm{RATE})$ & $\begin{array}{l}-0.019 \\
(0.127)\end{array}$ & $\begin{array}{c}0.030 \\
(0.139)\end{array}$ & $\begin{array}{c}-0.733^{* *} \\
(0.118)\end{array}$ \\
\hline $\mathrm{ADR}$ & $\begin{array}{c}-2.546^{* *} \\
(0.060)\end{array}$ & $\begin{array}{c}-0.540^{* *} \\
(0.051)\end{array}$ & $\begin{array}{c}-1.934^{* *} \\
(0.054)\end{array}$ \\
\hline Log(POLICY LIMIT) & $\begin{array}{c}-0.235^{* *} \\
(0.023)\end{array}$ & $\begin{array}{c}-0.125^{* *} \\
(0.027)\end{array}$ & $\begin{array}{c}-0.323^{* *} \\
(0.022)\end{array}$ \\
\hline EMPLOYED & $\begin{array}{l}-0.054 \\
(0.049)\end{array}$ & $\begin{array}{c}-0.131^{*} \\
(0.053)\end{array}$ & $\begin{array}{c}-0.102^{*} \\
(0.046)\end{array}$ \\
\hline $\log (\mathrm{AGE}+1)$ & $\begin{array}{l}-0.025 \\
(0.035)\end{array}$ & $\begin{array}{l}0.100^{* *} \\
(0.034)\end{array}$ & $\begin{array}{c}0.034 \\
(0.031)\end{array}$ \\
\hline MULTIDEF & $\begin{array}{c}-0.289^{* *} \\
(0.011)\end{array}$ & $\begin{array}{c}-0.178^{* *} \\
(0.012)\end{array}$ & $\begin{array}{c}-0.169^{* *} \\
(0.011)\end{array}$ \\
\hline INDIVDEF & $\begin{array}{c}-0.201^{* *} \\
(0.023)\end{array}$ & $\begin{array}{c}-0.156^{* *} \\
(0.025)\end{array}$ & $\begin{array}{l}-0.048^{*} \\
(0.023)\end{array}$ \\
\hline Nonfatal Serious Injuries & $\begin{array}{c}-1.205^{* *} \\
(0.117)\end{array}$ & $\begin{array}{c}-1.008^{* *} \\
(0.106)\end{array}$ & $\begin{array}{c}-0.559^{* *} \\
(0.099)\end{array}$ \\
\hline Fatality & $\begin{array}{c}-0.637^{* *} \\
(0.077)\end{array}$ & $\begin{array}{c}-0.839^{* *} \\
(0.072)\end{array}$ & $\begin{array}{c}-0.178^{* *} \\
(0.066)\end{array}$ \\
\hline General liability & $\begin{array}{c}-0.564^{* *} \\
(0.012)\end{array}$ & $\begin{array}{c}-0.401^{* *} \\
(0.014)\end{array}$ & $\begin{array}{c}-0.235^{* *} \\
(0.012)\end{array}$ \\
\hline Multiperil liability & $\begin{array}{c}-0.385^{* *} \\
(0.014)\end{array}$ & $\begin{array}{c}-0.268^{* *} \\
(0.016)\end{array}$ & $\begin{array}{c}-0.097^{* *} \\
(0.014)\end{array}$ \\
\hline Med Mal & $\begin{array}{c}-0.585^{* *} \\
(0.022)\end{array}$ & $\begin{array}{c}-0.226^{* *} \\
(0.024)\end{array}$ & $\begin{array}{c}-0.112^{* *} \\
(0.022)\end{array}$ \\
\hline Other professional liability & $\begin{array}{c}-0.490^{* *} \\
(0.043)\end{array}$ & $\begin{array}{c}-0.216^{* *} \\
(0.048)\end{array}$ & $\begin{array}{l}-0.073 \\
(0.043)\end{array}$ \\
\hline \multicolumn{4}{|l|}{ Time-Dependence Parameters } \\
\hline Log(COURT DELAY) & $\begin{array}{c}-0.218^{* *} \\
(0.007)\end{array}$ & $\begin{array}{c}-0.035^{* *} \\
(0.007)\end{array}$ & - \\
\hline Log(COURT DELAY-1) & $\begin{array}{l}- \\
-\end{array}$ & $\begin{array}{l}- \\
-\end{array}$ & $\begin{array}{c}-0.127^{* *} \\
(0.027)\end{array}$ \\
\hline $\log (\mathrm{RATE})$ & $\begin{array}{l}-0.045 \\
(0.038)\end{array}$ & $\begin{array}{c}-0.084^{\dagger} \\
(0.046)\end{array}$ & $\begin{array}{c}0.215^{* *} \\
(0.037)\end{array}$ \\
\hline ADR & $\begin{array}{c}0.691^{* *} \\
(0.017)\end{array}$ & $\begin{array}{c}0.210^{* *} \\
(0.017)\end{array}$ & $\begin{array}{c}0.541^{* *} \\
(0.016)\end{array}$ \\
\hline Log(POLICY LIMIT) & $\begin{array}{c}0.061^{* *} \\
(0.007)\end{array}$ & $\begin{array}{c}0.033^{* *} \\
(0.009)\end{array}$ & $\begin{array}{c}0.092^{* *} \\
(0.007)\end{array}$ \\
\hline EMPLOYED & $\begin{array}{c}0.001 \\
(0.015)\end{array}$ & $\begin{array}{l}0.031^{\dagger} \\
(0.017)\end{array}$ & $\begin{array}{c}0.019 \\
(0.015)\end{array}$ \\
\hline $\log (\mathrm{AGE}+1)$ & $\begin{array}{c}0.027^{* *} \\
(0.010)\end{array}$ & $\begin{array}{l}-0.012 \\
(0.011)\end{array}$ & $\begin{array}{c}0.007 \\
(0.010)\end{array}$ \\
\hline
\end{tabular}




\begin{tabular}{|c|c|c|c|}
\hline & $\begin{array}{l}\text { Time between } \\
\text { Injury \& Closure } \\
(N=54,760)\end{array}$ & $\begin{array}{l}\text { Time between } \\
\text { Filing \& Closure } \\
\quad(N=38,829)\end{array}$ & $\begin{array}{l}\text { Time Between } \\
\text { Claim \& Closure } \\
(N=54,760)\end{array}$ \\
\hline Variable & $\begin{array}{c}\log \\
(\text { DURATION-1) }\end{array}$ & $\begin{array}{c}\text { Log } \\
(\text { DURATION-2) }\end{array}$ & $\begin{array}{c}\text { Log } \\
(\text { DURATION) }\end{array}$ \\
\hline \multicolumn{4}{|l|}{ Time-Dependence Parameters } \\
\hline Nonfatal Serious Injuries & $\begin{array}{l}-0.106 \\
(0.080)\end{array}$ & $\begin{array}{c}-0.113^{* *} \\
(0.037)\end{array}$ & $\begin{array}{l}0.300^{* *} \\
(0.033)\end{array}$ \\
\hline Fatality & $\begin{array}{c}-0.492^{* *} \\
(0.056)\end{array}$ & $\begin{array}{c}-0.279^{* *} \\
(0.025)\end{array}$ & $\begin{array}{l}0.151^{* *} \\
(0.022)\end{array}$ \\
\hline Log likelihood & $-537,972.99$ & $-370,448.2$ & $-543,484.91$ \\
\hline \multicolumn{4}{|c|}{$\begin{array}{l}\text { Noте.- Standard errors are shown in parentheses. } \dagger \text { significant at } 10 \text { percent level; } * \text { significant at } 5 \text { percent level; ** } \\
\text { significant at } 1 \text { percent level. Omitted injury type is other nonfatal injuries. Omitted insurance policy type is auto } \\
\text { liability. The source for these values is author's calculations based on the Texas Department of Insurance Commercial } \\
\text { Liability Insurance Closed Claim database for the period August } 2003-2008 \text { for claims with indemnity payments of at } \\
\text { least } \$ 25,000 \text { in nominal value. Column } 2 \text { restricts to claims for which a suit is filed. Duplicate reports relating to the } \\
\text { same incident in the same year are excluded; duplicate reports filed in different years are not identified and eliminated. }\end{array}$} \\
\hline
\end{tabular}

claim submission across cases. ${ }^{47}$ But the process of settlement negotiation begins with the victim's demand for compensation rather than the event of injury. An second exception is for the effect of ADR reported in the column 2 of Table 5. The positive time-dependence effect of ADR overcomes the negative baseline effect quickly. The net effects, judged within the observed range of durations are inconsistent with the estimates in column 2 of Table 4. Together with the results reported in Table 4, this result suggests that ADR mainly displays an adverse effect on the settlement hazard among claims in which no suit is filed.

\section{B. Alternative Court Delay Indicator}

As a second robustness check, I test whether my results are robust to alternative definition of trialcourt delay. I rerun the specification in the second column of Table 4 for the bargaining sample but measure the speed of court proceedings by COURT DELAY-1 - the time required for a case to reach trial from the date of filing. The variable controls for district-year specific determinants of settlement duration. The coefficients in column 3 of Table 5 show that my results are robust to alternative definition of trial-court delay.

\section{Decomposition of Results by Insurance Line}

I decompose the bargaining sample into five subsamples for each insurance line to account for possible differences in bargaining behavior and to investigate on which insurance lines the legal system displays the greatest effect on the settlement duration. I rerun the model in column 2 of Table 4 for each insurance line respectively. Estimates of the baseline coefficients and the time-dependence coefficients are presented in Table 6 .

\footnotetext{
${ }^{47}$ Calculations (not reported in the tables) based on the TDI data for the period August 1, 2003 to December 31 , 2008 for claims with indemnity payments of at least $\$ 25,000$ in nominal value shows that the standard deviation of time between injury and termination is approximately 53.1 months.
} 
Table 6. Cox Regression Parameter Estimates for Pre-Verdict Settlements by Insurance Type

\begin{tabular}{|c|c|c|c|c|c|}
\hline & $\begin{array}{c}\text { Auto } \\
\text { Liability } \\
(N=28,190)\end{array}$ & $\begin{array}{c}\text { General } \\
\text { Liability } \\
(N=9,977)\end{array}$ & $\begin{array}{c}\text { Multiperil } \\
\text { Liability } \\
(N=6,752)\end{array}$ & $\begin{array}{c}\text { Medical } \\
\text { Malpractice } \\
\text { Liability } \\
(N=9,276)\end{array}$ & $\begin{array}{c}\text { Other } \\
\text { Professional } \\
\text { Liability } \\
(N=565)\end{array}$ \\
\hline Variable & $\begin{array}{c}\text { Log } \\
(\text { DURATION) }\end{array}$ & $\begin{array}{c}\log \\
(\mathrm{DURATION})\end{array}$ & $\begin{array}{c}\log \\
(\mathrm{DURATION})\end{array}$ & $\begin{array}{c}\log \\
(\text { DURATION) }\end{array}$ & $\begin{array}{c}\log \\
(\text { DURATION) }\end{array}$ \\
\hline \multicolumn{6}{|l|}{ Baseline Parameters } \\
\hline Log(COURT DELAY) & $\begin{array}{c}0.808^{* *} \\
(0.032)\end{array}$ & $\begin{array}{c}0.658^{* *} \\
(0.050)\end{array}$ & $\begin{array}{c}0.644^{* *} \\
(0.058)\end{array}$ & $\begin{array}{c}0.430^{* *} \\
(0.056)\end{array}$ & $\begin{array}{l}0.323^{\dagger} \\
(0.193)\end{array}$ \\
\hline $\log (\mathrm{RATE})$ & $\begin{array}{l}-0.039 \\
(0.157)\end{array}$ & $\begin{array}{c}-0.420^{\dagger} \\
(0.308)\end{array}$ & $\begin{array}{c}-0.605^{\dagger} \\
(0.369)\end{array}$ & $\begin{array}{c}-1.643^{* *} \\
(0.370)\end{array}$ & $\begin{array}{l}-0.989 \\
(1.424)\end{array}$ \\
\hline ADR & $\begin{array}{c}-2.684^{* *} \\
(0.082)\end{array}$ & $\begin{array}{c}-1.189^{* *} \\
(0.118)\end{array}$ & $\begin{array}{c}-1.773^{* *} \\
(0.140)\end{array}$ & $\begin{array}{c}-0.251^{* *} \\
(0.034)\end{array}$ & $\begin{array}{c}-1.473^{* *} \\
(0.492)\end{array}$ \\
\hline Log(POLICY LIMIT) & $\begin{array}{c}-0.370^{* *} \\
(0.029)\end{array}$ & $\begin{array}{c}-0.554^{* *} \\
(0.060)\end{array}$ & $\begin{array}{c}-0.309^{* *} \\
(0.120)\end{array}$ & $\begin{array}{l}-0.077 \\
(0.055)\end{array}$ & $\begin{array}{l}-0.001 \\
(0.233)\end{array}$ \\
\hline EMPLOYED & $\begin{array}{l}-0.097 \\
(0.064)\end{array}$ & $\begin{array}{l}-0.020 \\
(0.116)\end{array}$ & $\begin{array}{c}-0.265^{*} \\
(0.132)\end{array}$ & $\begin{array}{c}-0.326^{*} \\
(0.129)\end{array}$ & $\begin{array}{c}0.690 \\
(0.428)\end{array}$ \\
\hline $\log (\mathrm{AGE}+1)$ & $\begin{array}{c}-0.239^{* *} \\
(0.057)\end{array}$ & $\begin{array}{c}0.057 \\
(0.089)\end{array}$ & $\begin{array}{c}0.300^{* *} \\
(0.094)\end{array}$ & $\begin{array}{l}0.117^{*} \\
(0.053)\end{array}$ & $\begin{array}{l}-0.202 \\
(0.255)\end{array}$ \\
\hline MULTIDEF & $\begin{array}{c}-0.179^{* *} \\
(0.020)\end{array}$ & $\begin{array}{c}-0.079^{* *} \\
(0.022)\end{array}$ & $\begin{array}{c}-0.132^{* *} \\
(0.027)\end{array}$ & $\begin{array}{c}-0.172^{* *} \\
(0.022)\end{array}$ & $\begin{array}{c}-0.248^{* *} \\
(0.095)\end{array}$ \\
\hline INDIVDEF & $\begin{array}{c}0.041 \\
(0.116)\end{array}$ & $\begin{array}{c}0.138 \\
(0.201)\end{array}$ & $\begin{array}{l}-0.033 \\
(0.126)\end{array}$ & $\begin{array}{l}-0.035 \\
(0.028)\end{array}$ & $\begin{array}{c}0.153 \\
(0.150)\end{array}$ \\
\hline Nonfatal Serious Injuries & $\begin{array}{l}-0.254 \\
(0.162)\end{array}$ & $\begin{array}{c}0.031 \\
(0.213)\end{array}$ & $\begin{array}{c}0.115 \\
(0.265)\end{array}$ & $\begin{array}{c}-1.257^{* *} \\
(0.212)\end{array}$ & $\begin{array}{l}-0.014 \\
(0.907)\end{array}$ \\
\hline Fatality & $\begin{array}{l}0.818^{* *} \\
(0.107)\end{array}$ & $\begin{array}{c}0.041 \\
(0.162)\end{array}$ & $\begin{array}{c}0.112 \\
(0.201)\end{array}$ & $\begin{array}{c}-0.898^{* *} \\
(0.137)\end{array}$ & $\begin{array}{l}-0.334 \\
(0.494)\end{array}$ \\
\hline
\end{tabular}

(Continued overleaf) 


\begin{tabular}{|c|c|c|c|c|c|}
\hline & $\begin{array}{c}\text { Auto } \\
\text { Liability } \\
(N=28,190)\end{array}$ & $\begin{array}{c}\text { General } \\
\text { Liability } \\
(N=9,977) \\
\end{array}$ & $\begin{array}{c}\text { Multiperil } \\
\text { Liability } \\
(N=6,752) \\
\end{array}$ & $\begin{array}{c}\text { Medical } \\
\text { Malpractice } \\
\text { Liability } \\
(N=9,276)\end{array}$ & $\begin{array}{c}\text { Other } \\
\text { Professional } \\
\text { Liability } \\
(N=565)\end{array}$ \\
\hline Variable & $\begin{array}{c}\log \\
(\mathrm{DURATION}) \\
\end{array}$ & $\begin{array}{c}\log \\
(\mathrm{DURATION}) \\
\end{array}$ & $\begin{array}{c}\log \\
(\mathrm{DURATION}) \\
\end{array}$ & $\begin{array}{c}\log \\
(\mathrm{DURATION}) \\
\end{array}$ & $\begin{array}{c}\text { Log } \\
\text { (DURATION) }\end{array}$ \\
\hline \multicolumn{6}{|l|}{ Time-Dependence Parameters } \\
\hline Log(COURT DELAY) & $\begin{array}{c}-0.183^{* *} \\
(0.010)\end{array}$ & $\begin{array}{c}-0.148^{* *} \\
(0.015)\end{array}$ & $\begin{array}{c}-0.155^{* *} \\
(0.018)\end{array}$ & $\begin{array}{c}-0.099^{* *} \\
(0.017)\end{array}$ & $\begin{array}{l}-0.036 \\
(0.060)\end{array}$ \\
\hline $\log (\mathrm{RATE})$ & $\begin{array}{l}-0.027 \\
(0.051)\end{array}$ & $\begin{array}{c}0.105 \\
(0.094)\end{array}$ & $\begin{array}{l}0.200^{*} \\
(0.116)\end{array}$ & $\begin{array}{l}0.278^{*} \\
(0.110)\end{array}$ & $\begin{array}{c}0.091 \\
(0.443)\end{array}$ \\
\hline $\mathrm{ADR}$ & $\begin{array}{c}0.728^{* *} \\
(0.025)\end{array}$ & $\begin{array}{l}0.353^{* *} \\
(0.035)\end{array}$ & $\begin{array}{c}0.506^{* *} \\
(0.043)\end{array}$ & $\begin{array}{c}0.117^{* *} \\
(0.041)\end{array}$ & $\begin{array}{c}0.438^{* *} \\
(0.153)\end{array}$ \\
\hline Log(POLICY LIMIT) & $\begin{array}{c}0.106^{* *} \\
(0.010)\end{array}$ & $\begin{array}{c}0.164^{* *} \\
(0.018)\end{array}$ & $\begin{array}{c}0.110^{* *} \\
(0.038)\end{array}$ & $\begin{array}{c}0.010 \\
(0.016)\end{array}$ & $\begin{array}{l}-0.001 \\
(0.074)\end{array}$ \\
\hline EMPLOYED & $\begin{array}{c}0.025 \\
(0.020)\end{array}$ & $\begin{array}{l}-0.006 \\
(0.035)\end{array}$ & $\begin{array}{c}0.063 \\
(0.041)\end{array}$ & $\begin{array}{l}0.093^{*} \\
(0.039)\end{array}$ & $\begin{array}{c}-0.219^{\dagger} \\
(0.134)\end{array}$ \\
\hline $\log (\mathrm{AGE}+1)$ & $\begin{array}{c}0.076^{* *} \\
(0.018)\end{array}$ & $\begin{array}{c}0.001 \\
(0.027)\end{array}$ & $\begin{array}{c}-0.078^{* *} \\
(0.029)\end{array}$ & $\begin{array}{l}-0.012 \\
(0.016)\end{array}$ & $\begin{array}{c}0.075 \\
(0.078)\end{array}$ \\
\hline Nonfatal Serious Injuries & $\begin{array}{c}0.057 \\
(0.050)\end{array}$ & $\begin{array}{l}-0.013 \\
(0.064)\end{array}$ & $\begin{array}{l}-0.061 \\
(0.081)\end{array}$ & $\begin{array}{c}0.361^{* *} \\
(0.063)\end{array}$ & $\begin{array}{l}-0.005 \\
(0.283)\end{array}$ \\
\hline Fatality & $\begin{array}{c}-0.250^{* *} \\
(0.035)\end{array}$ & $\begin{array}{l}-0.037 \\
(0.048)\end{array}$ & $\begin{array}{l}-0.049 \\
(0.062)\end{array}$ & $\begin{array}{c}0.259^{* *} \\
(0.042)\end{array}$ & $\begin{array}{c}0.088 \\
(0.153)\end{array}$ \\
\hline Log Likelihood & $-259,437.62$ & $-82,072.24$ & $-52,813.8$ & $-75,702.85$ & $-3,013.65$ \\
\hline
\end{tabular}

Note.- Standard errors are shown in parentheses. † significant at 10 percent level; * significant at 5 percent level; ** significant at 1 percent level. Omitted injury type is other nonfatal injuries.

Source: Author's calculations based on the Texas Department of Insurance Commercial Liability Insurance Closed Claim database for the period August 2003-2008 for claims with indemnity payments of at least $\$ 25,000$ in nominal value. Duplicate reports relating to the same incident in the same year are exclude; duplicate reports filed in different years are not identified and eliminated. 
It turns out that while the magnitudes of the effects of the legal systems vary, all of the earlier results still hold, with exception for the effect of prejudgment interest in other professional liability claims. The baseline and time-dependence coefficients of RATE, reported in column 5 of Table 6 are statistically insignificant, in part because of the smaller sample size (565).

Furthermore, the estimated effect of RATE is negative but small and statistically insignificant in auto liability claims where court awards tend to be low. In contrast, the adverse effect of RATE is large in medical malpractice claims where trial stakes tends to be high (see Table 3, Panel B). These observations are consistent with the comparative statics of Spier's model where prejudgment interest increases the duration of settlement through increasing the trial value and where a high level of court awards accentuates the adverse effect of prejudgment interest. ${ }^{48}$

\section{Alternative Sample Period}

Until this point, we have considered claims resolved after August 1, 2003. Now I examine whether my results hold for settlements before August 1, 2003. I rerun the specification in the second column of Table 4 for "Long Form" reports for the period 1988 to July 2003. In a similar way to the earlier analysis, duplicate reports relating to the same incident in the same year are excluded. Because RATE fixed at 10 percent a year before August 2003, I exclude it as an explanatory variable. The descriptive statistics for this sample are reported in the appendix. Estimates of the baseline and the time-dependence coefficients are presented in Table 6 . The table shows that the effects of the legal institutions and the bargaining environment on the settlement hazard are robust to alternative sample choices.

\section{Conclusion}

The social costs of delay in the resolution of legal disputes have motivated an extensive literature investigating its causes. However, much less work has investigated a related and more policy-relevant question: how do legal systems affect delay in settlement? To address this question, I adapt a model developed by Spier (1992) where the defendant has private information about the trial outcome and pretrial negotiation takes place over a finite period of time prior to a fixed trial date. In the absence of direct information on the trial outcome, the plaintiff presents the defendant with an decreasing sequence of offers. Facing such a schedule, high type defendants will settle early for higher damage payments, while low type defendants will be prepared to delay agreement until settlement offers drop. The model predicts that the duration of settlement is influenced by variables reflecting the legal system. These include the magnitude of trial-court delay, the level of the prejudgment interest rate and the costs of litigation. Using the Texas Department of Insurance Commercial Liability Insurance Closed Claim database for the years 1988-2008, I estimate the influence of these institutional factors on the timing of settlement and present three major findings.

\footnotetext{
${ }^{48}$ Differentiating (8) twice, we have that $\frac{\partial^{2} h}{\partial R \partial \pi}>0$.
} 
Table 6. Cox Regression Parameter Estimates for Pre-Verdict Settlements Before August 1, $2003(N=84,975)$

\begin{tabular}{|c|c|}
\hline Variable & Log(DURATION) \\
\hline \multicolumn{2}{|l|}{ Baseline Parameters } \\
\hline Log(COURT DELAY) & $\begin{array}{c}-0.099^{* *} \\
(0.015)\end{array}$ \\
\hline $\mathrm{ADR}$ & $\begin{array}{c}-1.690^{* *} \\
(0.047)\end{array}$ \\
\hline Log(POLICY LIMIT) & $\begin{array}{c}-0.291^{* *} \\
(0.018)\end{array}$ \\
\hline EMPLOYED & $\begin{array}{c}-0.214^{* *} \\
(0.038)\end{array}$ \\
\hline $\log (\mathrm{AGE}+1)$ & $\begin{array}{l}0.119^{* *} \\
(0.025)\end{array}$ \\
\hline MULTIDEF & $\begin{array}{c}-0.260^{* *} \\
(0.008)\end{array}$ \\
\hline INDIVDEF & $\begin{array}{l}-0.002 \\
(0.019)\end{array}$ \\
\hline Nonfatal Serious Injuries & $\begin{array}{c}-0.464^{* *} \\
(0.078)\end{array}$ \\
\hline Fatality & $\begin{array}{c}-0.141^{* *} \\
(0.054)\end{array}$ \\
\hline General liability & $\begin{array}{c}-0.366^{* *} \\
(0.009)\end{array}$ \\
\hline Multiperil liability & $\begin{array}{c}-0.083^{* *} \\
(0.010)\end{array}$ \\
\hline Med Mal & $\begin{array}{c}-0.100^{* *} \\
(0.018)\end{array}$ \\
\hline Other professional liability & $\begin{array}{c}-0.108^{* *} \\
(0.035)\end{array}$ \\
\hline \multicolumn{2}{|l|}{ Time-Dependence Parameters } \\
\hline $\log ($ COURT DELAY $)$ & $\begin{array}{c}0.037^{* *} \\
(0.005)\end{array}$ \\
\hline $\mathrm{ADR}$ & $\begin{array}{c}0.494^{* *} \\
(0.014)\end{array}$ \\
\hline Log(POLICY LIMIT) & $\begin{array}{l}0.099^{* *} \\
(0.006)\end{array}$ \\
\hline EMPLOYED & $\begin{array}{l}0.052^{* *} \\
(0.012)\end{array}$ \\
\hline $\log (\mathrm{AGE}+1)$ & $\begin{array}{c}-0.026^{* *} \\
(0.007)\end{array}$ \\
\hline Nonfatal Serious Injuries & $\begin{array}{l}0.113^{* *} \\
(0.023)\end{array}$ \\
\hline Fatality & $\begin{array}{l}0.044^{* *} \\
(0.016)\end{array}$ \\
\hline
\end{tabular}

Log likelihood

$-881,120.83$

Note.- Standard errors are shown in parentheses. $\dagger$ significant at 10 percent level; * significant at 5 percent level; ${ }^{* *}$ significant at 1 percent level. Omitted injury type is other nonfatal injuries. Omitted insurance policy type is auto liability. The source for these values is author's calculations based on the Texas Department of Insurance Commercial Liability Insurance Closed Claim database for the period 1988-July 2003 for claims with indemnity payments of at least $\$ 25,000$ in nominal value. Duplicate reports relating to the same incident in the same year are excluded; duplicate reports filed in different years are not identified and eliminated. 
My empirical work shows that longer delays in trial courts are associated with shorter delays in out-of-court settlement. This finding suggests that policies that streamline the court system by reducing court congestion may have the unintended effect of prolonging delay in settlements. Further, I show that increases in prejudgment interest rate have statistically significant adverse effect on the duration of settlement. This observation is consistent with a theoretic model where the defendant has private information about the trial outcome and higher damage awards provide a plaintiff with a greater incentive to prolong litigation. Finally, alternative dispute resolution, a legal process designed to reduce legal costs, actually increases delay in settlement, controlling for other institutional factors and the characteristics of claims. Taken together, these results suggest that policy makers and the proponents of legal reform must be more sophisticated than they have been in designing policies for expediting the resolution of legal disputes.

The analysis relies on a number of simplifying assumptions. In particular, the analysis assumes that both parties are risk neutral. This is a reasonable assumption for the defendant. But plaintiffs are usually risk averse, which would provide additional incentive to avoid a risky trial and settle early. Furthermore, the analysis abstracts from agency problems in the lawyer-client relationship. ${ }^{49}$ There is a need for more theoretical and empirical analysis that studies the role of agency problems in delaying settlement. This analysis also ignores the effect of liability rules. Kessler (1996) shows, for instance, comparative negligence moves the distribution of settlement times significantly backward.

A further avenue for research involves theoretical and empirical investigation of fee-shifting provisions that are typically included in some of the ADR proceedings (e.g., court-annexed arbitrations). The present analysis could not distinguish whether the adverse effect of the ADR programs on settlement hazard reflects the low costs of such programs or the impact of fee-shifting arrangements. Another angle is to see how choices regarding ADR proceedings might signal information about the case.

Nevertheless, on balance, the evidence in favor the screening interpretation of settlement delay is strong. Spier's (1992) screening model does provide a simple but theoretically consistent way of analyzing delay determinants, and it does receive some empirical support. My interpretation is that is a promising way of bringing some understanding to the empirical regularities in this complex area.

\footnotetext{
${ }^{49}$ See Miller (1987) and Zhou (2010), Chapter 5.
} 
Appendix: Descriptive Statistics for Period 1988-July 2003

Table 3: Descriptive Statistics

Panel C. Legal System and Bargaining Environment before August 1, 2003

\begin{tabular}{lcc}
\hline \hline & Mean & Std. Dev. \\
\hline LEGAL SYSTEM & & \\
COURT DELAY (months) & 4.5 & 6.5 \\
RATE (\%) & 10 & 0 \\
ADR (1=yes) & 0.25 & 0.44 \\
BARGAINING ENVIRONMENT & & \\
POLICY LIMIT (\$) & $1,731,363$ & $4,784,248$ \\
EMPLOYED (1=yes) & 0.63 & 0.48 \\
AGE (years) & 39.9 & 18.7 \\
MULTIDEF (1=yes) & 0.32 & 0.47 \\
INDIVDEF (1=yes) & 0.13 & 0.33 \\
\hline
\end{tabular}

Observations

84,975

Note.- All dollar values are in 2008 \$. The source for these values is author's calculations based on the Texas Department of Insurance Commercial Liability Insurance Closed Claim database for the period 1988-July 2003 for claims with indemnity payments of at least $\$ 25,000$ in nominal value. Duplicate reports relating to the same incident in the same year are excluded; duplicate reports filed in different years are not identified and eliminated.

\section{References}

[1] Bebchuk, L. A. (1984): "Litigation and Settlement under Incomplete Information", Rand Journal of Economics, 15, pp. 404-15.

[2] Black, Bernard, Charles Silver, David A. Hyman, and William M. Sage. 2005. "Stability, Not Crisis: Medical Malpractice Claim Outcomes in Texas, 1988-2002," Journal of Empirical Legal Studies, 2 pp. 207-59.

[3] — 2008. "Defense Costs and Insurer Reserves in Medical Malpractice and Other Personal Injury Cases: Evidence from Texas, 1988-2004," American Law and Economics Review, 10, pp. 185-245.

[4] Black, Bernard, David A. Hyman, and Charles Silver. 2009. "The Effects of 'Early Offers' in Medical Malpractice Cases: Evidence from Texas" Journal of Empirical Legal Studies, 6. pp. 723-767.

[5] - 2010. "O'Connell Early Settlement Offers: Toward Realistic Numbers and Two-Sided Offers," Journal of Empirical Legal Studies, 7. pp. 379-401.

[6] Calhoun, P. T. (1990): “The Continuing Debate Over Delay Damages: Pennsyvania's New Rule 238", Villanova Law Review, 35, pp. 457-75.

[7] Carrington, P (1969): "Crowded Dockets and the Courts of Appeals, The Threat to the Function of Review and the National Law", Harvard Law Review, 82, pp. 542-617. 
[8] Cummins, J. D. and Weiss, M. A. (1993): "The Stochastic Dominance of No-Fault Automobile Insurance", The Journal of Risk and Insurance, 60, pp. 230-64.

[9] Cooter, R., Marks, S. \& Mnookin, R. (1982): "Bargaining in the Shadow of the Law: A Testable Model for Strategic Behavior", Journal of Legal Studies 11, pp. 225.

[10] Danzon P. M. and Lillard L. A. (1983): "Settlement out of Court: The Disposition of Medical Malpractice Claims", The Journal of Legal Studies 12, pp. 345-77.

[11] Daughety, A. F. and Reinganum, J. F. (2005): "Economomic Theories of Settlement Bargaining", Annual Review of Law and Social Science, 1, pp. 35-59.

[12] Deffains B. and Doriat M. (1999): "The Dynamics of Pretrial Negotiation In France: - Is There a Deadline Effect In The French Legal System?" International Review of Law and Economics 19, pp. $447-70$.

[13] Dewees, Don, David Duff, and Michael Trebilcock. (1996): Exploring the Domain of Accident Law. New York: Oxford University Press.

[14] Eisenberg, T., and Farber, H. S. (1997): "The Litigious Plaintiff Hypothesis: Case Selection and Resolution", Rand Journal of Economics, 28, pp. 92-112.

[15] Farber, H. S., and White, M. J. (1991): "Medical Malpractice: An Empirical Examination of the Litigation Process", The RAND Journal of Economics, 22, pp. 199-217.

[16] Fenn, P. and Rickman, N. (1999): "Delay and Settlement in Litigation", Economic Journal, 109, pp. 476-91.

[17] Fenn, P. and Rickman, N. (2001): "Asymmetric Information and the Settlement of Insurance Claims", The Journal of Risk and Insurance, 68, pp. 615-630.

[18] Fournier, G. M. and Zuehlke T. W. (1998): "The Timing of Out-of-Court Settlements", The RAND Journal of Economics, 27, pp. 310-321.

[19] Gould, J. (1973): "The Economics of Legal Conflicts", The Journal of Legal Studies, 2, pp. 279-300.

[20] Hay, Bruce and Kathryn Spier (1973): "Settlement of Litigation", in Peter Newman, ed., The New Palgrave Dictionary of Economics and the Law, Macmillan Reference Limited. pp. 442-451.

[21] Hensler, D. H., Vaiana M., Kakalik J. and Peterson M. (1987): "Trends in Tort Litigation:. The Story Behind the Statistics", in RAND Institute for Civil Justice, R-3583-ICJ. Santa Monica: RAND Corporation.

[22] Hersch, J. and Viscusi, W. (2007): "Tort Liability Litigation Costs", American Law and Economic Review, 9, pp. 330-69.

[23] Hersch, Joni, O'Connell, Jeffrey, and W. Kip Viscusi. 2007. "An Empirical Assessment of Early Offer Reform for Medical Malpractice," The Journal of Legal Studies, 36, pp. 231-59. 
[24] Hersch, Joni, O'Connell, Jeffrey, and W. Kip Viscusi. 2010. "Reply to 'The Effects of 'Early Offers' in Medical Malpractice Cases: Evidence from Texas," Journal of Empirical Legal Studies, 7, pp. 164-173.

[25] Insurance Information Institute (2007), The I.I.I. Insurance Fact Book, New York: Insurance Information Institute.

[26] Judicial Council of California Civil Jury Instructions (2004), available at http://www.courtinfo.ca.gov/reference/documents/civiljuryinst.pdf.

[27] Kakalik, J. S., Selvin, M. and Pace, N. M. (1990): "Averting Gridlock: Strategies for Reducing Civil Delay in the Los Angeles Superior Court", RAND Note.

[28] Kennan, J., and Wilson, R. (1993): "Bargaining with Private Information", Journal of Economic Literature, 31, pp. 45-104.

[29] Kessler, D. (1996): "Institutional Causes of Delay in the Settlement of Legal Disputes", Journal of Law, Economics and Organization, 12, pp. 432-60.

[30] Kessler, D. P. and Rubinfeld, D. L. (2004): "Empirical Study of the Civil Justice System", National Bureau of Economic Research Working Paper 10825.

[31] Knoll, M. S. (1996): “A Primer on Prejudgment Interest”, Texas Law Review, 75, pp. 293-374.

[32] Kornhauser L. A, and Revesz R. L. (1994): "Multidefendant Settlements: The Impact Of Joint And Several Liability", Journal of Legal Studies, 23, pp. 41-76.

[33] Kritzer, H. (1989): "A Comparative Perspective on Settlement and Bargaining in Personal Injury Cases", Law \& Social Inquiry, 14, pp. 167-84.

[34] Lalive, R. and van Ours, J., and Zweimller, J. (2006): "How Changes in Financial Incentives Affect the Duration of Unemployment", Review of Economic Studies, 73, pp. 1009-38.

[35] Lord Chancellor's Department (1986): The Civil Justice Review Study, London: HMSO.

[36] MacCoun, R. J. (1991): "Unintended Consequences of Court Arbitration: A Cautionary Tale from New Jersey", Justice System Journal, 14, pp. 229-243, 251-256.

[37] Meyer, B. D. (1990): "Unemployment Insurance and Unemployment Spells", Econometrica, 58, pp. $757-82$.

[38] Micevska M. and Hazra, A. (2004): "The Problem of Court Congestion: Evidence from Indian Lower Courts", Discussion Papers on Development Policy Bonn, No 88.

[39] Miller G. P. (1987): "Some Agency Problems in Settlement" The Journal of Legal Studies, 16, pp. $189-215$.

[40] - (1997): "The Legal-Economic Analysis of Comparative Civil Procedure", The American Journal of Comparative Law, 45, pp. 905-18. 
[41] Nalebuff, B. (1987): "Credible Pretrial Negotiation", The RAND Journal of Economics, 18, pp. 198-210.

[42] Nimmer, R. (1978): "The Nature of System Change: Reform Impact on Criminal Courts", Chicago: American Bar Association.

[43] Pennsylvania Supreme Court Opnion (1981): Laudenberger v. Port Auth. of Allegheny County, 436 A.2d pp. 147, 149.

[44] P'ng, I. (1983): "Strategic Behavior in Suit, Settlement, and Trial", Bell Journal of Economics, 14, pp. 539-50.

[45] Philips, J. R. and Freeman, N. W. (2001): "Interest as Damages, Litigation Services Handbook: The Role Of The Financial Expert", Roman Weil et al. eds., 3d ed.

[46] Priest, G. L. and Klein, B. (1984): "The Selection of Disputes for Litigation", The Journal of Legal Studies, 13, pp. 1-55.

[47] Priest, G. L. (1989): "Private Litigants and the Court Congestion Problem", Boston University Law Review, 69, pp. 527-559.

[48] Spurr, S. J. (1997): "The Duration of Litigation", Law and Policy, 19, pp. 285-315.

[49] - (2000): "The Duration of Personal Injury Litigation", Research in Law and Economics, 19, pp. 223-246.

[50] Torre, A. (2003): "The Impact of Court Delays on the Prosecutor and the Defendant: An Economic Analysis", European Journal of Law and Economics, 16, pp. 91-111.

[51] Reinganum, J. and Wilde, L. (1986): "Settlement, Litigation, and the Allocation of Litigation Costs", Rand Journal of Economics, 17, pp. 557-68.

[52] Rubin, P. H. and Shepherd, J. M. (2007): "Tort Reform and Accidental Deaths", Journal of Law and Economics, 50, pp. 221-38.

[53] Rosenberg, M (1965): "Court Congestion; Status, Causes and Proposed Remedies", In Jones, H, The Courts, The Public and the Law explosion, Prentice Hall, Englewood Cliffs N.J.

[54] Rosenberg, J. D. and Folberg, H. J. (1994): "Alternative Dispute Resolution: An Empirical Analysis", Stanford Law Review, 46, pp. 1487-551.

[55] Schweizer, U. (1989): "Litigation and Settlement under Two-Sided Incomplete Information", The Review of Economic Studies, 56, pp. 163-78.

[56] Sharkey, C. M. (2005): "Unintended Consequences of Medical Malpractice Damages Caps", New York University Law Review, 80, pp. 391-512.

[57] Sieg, H. (2000): "Estimating a Bargaining Model with Asymmetric Information: Evidence from Medical Malpractice Disputes", Journal of Political Economy, 108, pp. 1006-21 . 
[58] Siegelman, P., and Waldfogel, J. (1999): "Toward a Taxonomy of Disputes: New Evidence through the Prism of the Priest/Klein Model", Journal of Legal Studies, 28, pp. 101-30.

[59] Spier, K. (1992): “The Dynamics of Pretrial Negotiation", Review of Economic Studies, 59, pp. 93-108.

[60] - (2007): "Litigation", in A. Mitchell Polinsky and Steven Shavell, eds., The Handbook of Law and Economics, North Holland.

[61] _ (2008): "Economics of Litigation", in Blume and Durlauf, eds., The New Palgrave Dictionary of Economics, 2nd ed., Palgrave McMillan.

[62] Texas Office of Consumer Credit Commission (2003)-(2008): Texas Finance Code, Chapter 304.

[63] Texas Department of Insurance (1998)-(2004): The Taxes Liability Insurance Closed Claim Annual Report, various years. Austin: Texas Department of Insurance.

[64] Varano, V. (1997): "Civil Procedure Reform in Italy", American Journal of Comparative Law, 45, pp. $657-74$.

[65] Vidmar, N., Gross, F., and Rose, M. R. (1998): "Jury Awards for Medical Malpractice and Post-Verdict Adjustments of Those Awards", DePaul Law Review, 48, pp. 265-301.

[66] Viscusi, W. K. (1988): "Product Liability Litigation With Risk Aversion", Journal of Legal Studies, XVII, pp. 101-21.

[67] Waldfogel, J. (1998): "Reconciling Asymmetric Information and Divergent Expectations Theories of Litigation", Journal of Law and Economics, 41, pp. 451-76.

[68] Wilson, J. D., Bosco, J. A. and Malone, S. P. (1986): "Prejudgment Interest in Personal Injury, Wrongful Death and Other Actions", Trial Lawyer's Guide, 30, pp. 105-228.

[69] Worthington, D. (1991). The Pace of Litigation in New South Wales: Lessons from the Trial, Civil Justice Research Centre, Law Foundation of New South wales.

[70] Yoon, A. (2004): "Mandatory Arbitration and Civil Litigation: An Empirical Study of Medical Malpractice Litigation in the West", American Law and Economics Review, 6, pp. 95-134.

[71] Zhou, J. (2010). Access to Justice: An Economic Approach, CentER PhD Thesis Series No. 249. 